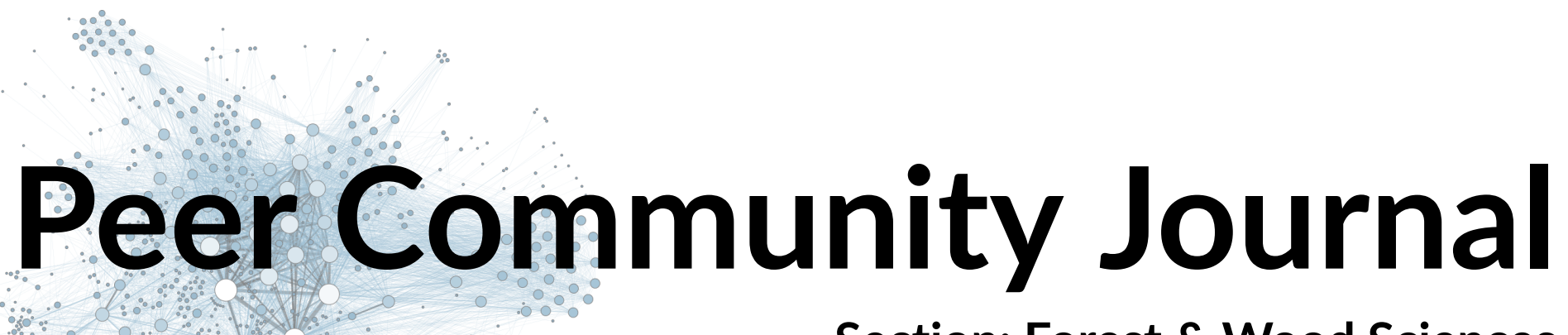

Section: Forest \& Wood Sciences

RESEARCH ARTICLE

\title{
Tree growth forces and wood properties
}

Published

2021-11-30

Cite as

Bernard Thibaut and Joseph

Gril (2021) Tree growth forces and wood properties, Peer

Community Journal, 1: e46.

Correspondence

bernard.thibaut@umontpellier.fr joseph.gril@cnrs.fr

Peer-review

Peer reviewed and recommended by

PCl Forest \& Wood Sciences,

https://doi.org/10.24072/pci. forestwoodsci.100006

\section{(cc) BY}

This article is licensed under the Creative Commons Attribution 4.0 License.

\section{Bernard Thibaut ${ }^{\oplus, 1}$ and Joseph Gril ${ }^{\oplus, 2,3}$}

\author{
Volume 1 (2021), article e46
}

https://doi.org/10.24072/pcjournal.48

\section{Abstract}

Living wood in the tree performs a muscular action by generating forces at the sapwood periphery and residual strains in dead sapwood fibres. Dissymmetric force generation around the tree trunk is the motor system allowing movement, posture control and tree reshaping after accidents. Rather young trees are able to restore the verticality of their trunk after accidental rotation of the soil-root system due to wind or landslide, leading to typically curved stems shape. The very high dissymmetry of forces for the motor action is associated with the occurrence of reaction wood on one side of the inclined stem during many successive years. A method to reconstitute this biomechanical history from observations after tree felling, on either green or dry wood, is discussed. A selection of 17 trees from 15 different species (13 different families), tropical and temperate, hardwoods and softwoods, were selected and peripheral residual strains were measured in situ before felling, on 8 positions for each stem. Matched wooden rods were sawn and measured for their mechanical and physical properties in the green and dry states, allowing the estimation of tree growth stress, i.e., the force created by the living wood. It was possible to build easy-to-use conversion coefficients between the growth stress indicator (GSI), measured in situ by the single hole method, and growth strain and growth stress with the knowledge of basic density and green longitudinal elastic modulus. Maturation strain, specific modulus (as a proxy of micro-fibril angle) and longitudinal shrinkage are properties independent from basic density, whose variation among species was very large. For the whole range of compression wood, normal wood and tension wood, strong relationships between these 3 properties were observed, but together no single model, based on cell-wall microfibril angle only, could be defined. Growth forces are the product of 4 parameters: ring width, basic density, basic specific modulus and maturation strain, all of them being the result of wood formation. Thanks to the wide range of wood types and species, simple and highly significant formulas were obtained for the relationship between basic and dry density, green and dry longitudinal modulus of elasticity, basic and dry specific modulus. To estimate ring width in the green state from values in dry state, radial shrinkage needs to be measured afterwards on dry specimens. Maturation strains is less accurately linked to late measurements on dry wood, but longitudinal shrinkage offers a rather good solution for an estimation provided that the wood type (softwood, hardwood with-G layer, hardwood without G-Layer) is known.

\footnotetext{
${ }^{1}$ LMGC, Univ Montpellier, CNRS, Montpellier, France, 2 Université Clermont Auvergne, CNRS, Institut Pascal, Clermont-Ferrand, France, ${ }^{3}$ Université Clermont Auvergne, INRAE, PIAF, Clermont-Ferrand, France
} 


\section{Introduction}

During the beginning of this $21^{\text {st }}$ century much has been done and written about the biomechanics of force and stress generation resulting from wood growth, following the $20^{\text {th }}$ century more dedicated to large measuring campaigns of wood properties to encompass their very large variability. Wood tissues fulfil several functions in the tree: tree growth, sap ascent, mechanical resistance to external forces, storage of water and numerous organic or mineral components, transfer of material and information between tree parts and the roots. During tree life, wood growth and properties adapt to tree environment so as to regulate each function in conjunction with the others. Consequently, wood variability results both from genetic speciation and from physiological adaption during the process of wood formation. Many studies dedicated to the hydraulic function link variations of wood structure and properties of different species to changes in water availability and, conversely, predict climatic variations using variations in wood structure and properties. Could the same be done with biomechanical functions? Assuming that they are successfully linked to wood growth, structure and property, would it be possible to read in wood specimens the trace of tree's biomechanical history?

\section{Basics of tree biomechanics}

The study of the residual stress resulting from tree growth started in the late 1920s. It was mostly measured at trunk periphery and its effects during the early stages of wood processing, such as end splitting of felled logs or warping of sawn timber, were described (Gril et al 2017). Models of stress distribution within a trunk were proposed (Archer 1986, Kubler 1987, Fournier et al 1991a, 1991b, Alméras et al 2018a).

Since the beginning of the 2000s the biological origin and function of large peripheral residual stress has been thoroughly investigated by experimental work at cell wall level together with biomechanical models of stress generation within wood fibres. From the mechanical viewpoint wood fulfils three basic functions in the tree: achievement of tree architecture (manufacturing), control of axis direction (posture control) and resistance to external forces (resistance) (Alméras et al 2009, Tocquard et al 2014, Thibaut 2019).

The following paragraphs give a synthetic overview of many results, often published in recent books or review articles cited in priority to avoid lengthy lists of references.

\section{Wood growth in mass and volume}

All wooden parts of a tree are slender beams (axis) clamped at the proximal end (junction). Such cantilever beams can be vertical (trunk), oblique or horizontal. Each axis is made of a succession of primary growth units (Barthélémy \& Caraglio 2007), results of the division of stem cells in primary meristems (buds). A portion of growth unit, between junctions, has the shape of a multi-layered cylinder with an inner skeleton of mostly dead fibre cells and pipe elements, a thin layer of living cells, with a nucleus and a cytoplasm, and an outer bark layer (Fahn 1990).

Wood formation, its growth in volume and mass, occurs through a 3D manufacturing process taking place in the thin intermediate living layer. At the cellular level the process requires three steps: cell division, cell expansion until final geometry, cell-wall thickening (maturation) until programmed cell death and full cell-wall lignification (Thibaut 2019). At the plant level it consists in axis lengthening by addition of new growth units and thickening of existing parts by addition of a new peripheral layer thickness. The mass increment all along the axis produce an increase of gravity forces and moments, together with an increase of sectional area and moment of inertia. The distribution of mechanical stress resulting from this manufacturing and the action of gravity (self-weight) is called support stress (Fournier et al 1991a). It vanishes at the periphery where the new wood has just been deposited.

\section{The generation of maturation forces}

During cell-wall thickening and maturation, the newly formed wood fibres generate growth forces (Alméras \& Clair 2016). The basic process of force generation is a small contraction or dilatation of the cell- 
wall polymer network. At the tissue level the resulting expansion is restrained by the rigid wood skeleton (Alméras et al 2018a). When the maturation process is completed, the so-called maturation strain $\left(\alpha_{m}\right)$ has been produced, while the longitudinal elastic modulus has reached a stable level $\left(E_{L}\right)$ and the initial maturation stress is set up as their product:

(1)

$$
\sigma_{m}=E_{L} \cdot \alpha_{m}
$$

Considering a layer portion of the newly formed wood of sectional area A, the growth force generated by the incremental wood growth in the longitudinal direction is:

$$
F=A . \sigma_{m}=A . E_{L} \cdot \alpha_{m}
$$

During each growth event, the local force generated by the cell maturation depends on ring width, wood elastic modulus and maturation strain. As a reaction to the effect of maturation in the newly formed wood layer, a counteracting stress is induced in the existing stem. The cumulative stress distribution resulting from the maturation process only, independently from gravity, is called the maturation stress.

\section{Residual or growth stresses: pre-stressing of the skeleton}

The total stress due to wood growth, called growth stress, is the sum of support stress and maturation stress (Fournier et al 1991b). The peripheral support stress being equal to zero, the peripheral stress equals the initial maturation stress $\sigma_{m}$. In an ideal tree growing with perfect symmetry, ring width, $E_{L}$ and $\underline{\alpha}_{\underline{m}}$ are the same all around the circumference. Since wood strength in the longitudinal (L) direction is more than two times higher in tension than compression (Markwardt \& Wilson 1935) the resulting uniform tensile pre-stressing at periphery enhances the resistance to bending (Gordon 1978, Gril et al 2017) which is the most dangerous situation for slender beams.

The growth stress can be estimated by different methods using strain gauges or strain transducers, measuring the strain associated to the stress release (Yoshida \& Okuyama 2002, Yang et al 2005, Clair et al 2013, Gril et al 2017). It has been usually observed at the sapwood periphery of standing trees, at different angular position and a given height level, but measurements of the internal distribution of residual stress were also performed through successive cutting and strain acquisitions. To obtain the local maturation force generated by a portion of recently formed wood, the measurement of the area (e.g., ring width) and elastic modulus is also needed. Numerous measurements on many trees have been performed in different contexts (Sasaki et al 1978, Okuyama et al 1994, Huang et al 2001, Alméras et al 2005b, Ruelle et al 2007, Jullien et al 2013). There is a clear difference between softwoods and hardwoods. For hardwoods, maturation strains are always associated with tensile maturation forces with a long tail of very high values, up to 5 times the most common value (Fig. 1). For softwoods on the contrary there is a tail associated with compressive values (Fournier et al 1994). Mean standard strain values (around $0.05 \%$ ) are associated to tensile stress for hardwoods (HW) and softwoods (SW). 


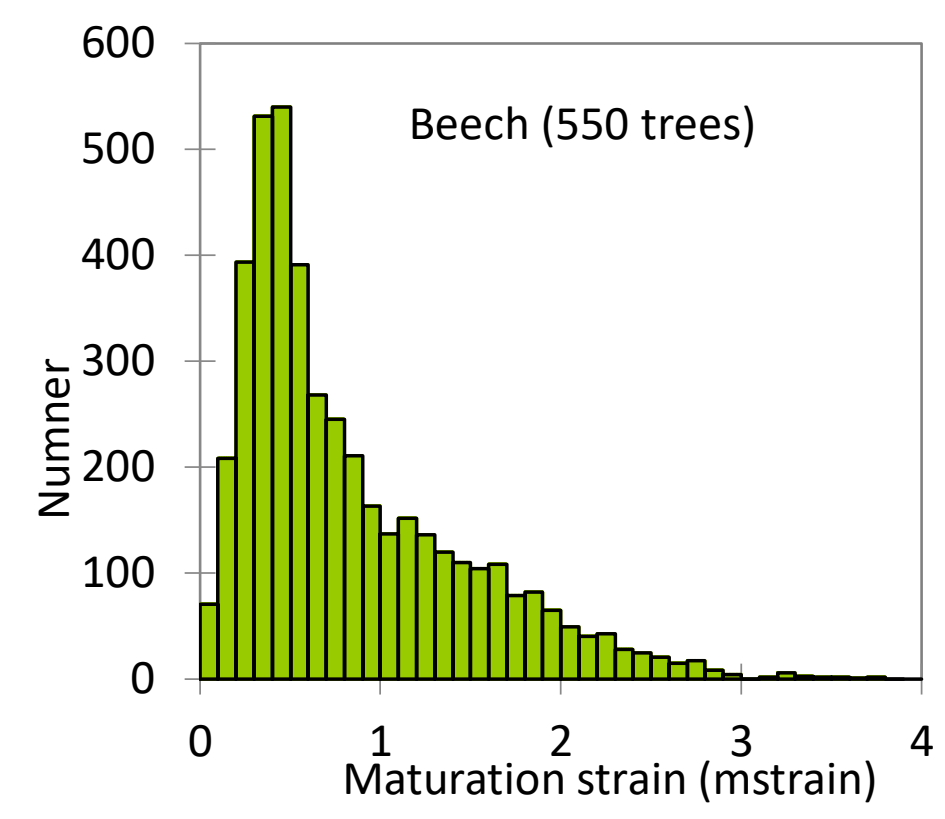

Figure 1. Distribution of maturation strains for 550 beech trees Data from Becker and Beimgraben (2001); mstrain: 1/1000.

Species is not a significant factor in the variations of $\alpha_{m}$. The most important factor is always the angular position within a tree at a given height (Alméras et al 2005b, Jullien et al 2013). Tree slenderness is also a significant factor for the mean maturation strain between trees: very slender trees have a higher mean level within a species (Jullien et al 2013). These slender trees have also a higher elastic modulus (Waghorn et al 2007, Watt et al 2008, Moore et al 2015) so that slender trees exhibit much higher $\sigma_{m}$ - but not always high $F$ because of their narrow rings.

\section{Normal wood and reaction wood}

Reaction wood (RW), either tension wood (TW) or compression wood (CW) were identified in the 1970s as the origin of the peculiar values of $\alpha_{m}$, very high tensile or compressive, respectively (Boyd 1972, Trénard and Guéneau 1975, Timell 1986, Okuyama et al 1994, Bamber 2001). A slightly more recent book "Biology of reaction wood" (Gardiner et al 2014) gives a state of the art concerning tension and compression wood for anatomy (Ruelle 2014), cell-wall polymers (Fagerstedt et al 2014), molecular mechanisms of induction (Tocquard et al 2014), biomechanical action (Fournier et al 2014), physical and mechanical properties (Clair \& Thibaut 2014). Most of recent developments were dedicated to TW. A new distinction is made between pure G-layer fibres, multi-layered G-fibres, late lignified G-fibres and no G-fibres (Ghislain \& Clair 2017, Higaki et al 2020). Further observations and model were discussed about cellulose within the G-layer (Chang et al 2015, Alméras \& Clair 2016, Gorshkowa et al 2018) with a relative consensus about a lattice structure of cellulose microfibrils in the G-layer.

Each wood species has a given pattern (signature) in sapwood anatomy and chemistry of the cell wall polymers: percentage of each basic polymer (cellulose, lignin, different types of hemicellulose) and $\mathrm{H}, \mathrm{G}, \mathrm{S}$ monomer proportions within the lignin. Normal wood (NW) is the most abundant wood type in a tree and both anatomy and chemistry have only small variations around the specific patterns. RW formation is triggered by specific genes and both their anatomical and chemical features differed markedly from the mean patterns (Table 1).

Associated variations in physical and mechanical properties differ between $\mathrm{CW}$ and TW as compared to NW. Basic density is always higher for CW in a given tree but the difference is often not significant for TW. Specific modulus of elasticity, which is very strongly linked to the microfibril angle (Cowdrey \& Preston 1966, Cave \& Hutt 1968), is always very low for CW and always high for TW, but for NW it can vary from very low for very juvenile wood to very high for resonant wood (Brémaud et al 2013). The total longitudinal shrinkage, always very low for NW (below $0.4 \%$ ), is much higher for CW (up to $4 \%$ ) and for TW (up to $1.5 \%$ ). 
Table 1. Variations in structure and chemistry for normal and reaction wood.

\begin{tabular}{|l|l|l|l|l|l|}
\hline Wood type & Anatomy & MFA & Lignin chemistry & Cellulose chemistry & Hemicellulose chemistry \\
\hline $\begin{array}{l}\text { Normal wood } \\
\text { (softwood) }\end{array}$ & $\begin{array}{l}\text { Standard } \\
\text { anatomy }\end{array}$ & $5^{\circ}-40^{\circ}$ & $\begin{array}{l}\text { Lignin content 25\%- } \\
38 \%\end{array}$ & $40 \%-60 \%$ & $\begin{array}{l}\text { Low } 6 \text { carbon sugar } \% \text { High } \\
5 \text { carbon sugars \% }\end{array}$ \\
\hline $\begin{array}{l}\text { Normal wood } \\
\text { (hardwood) }\end{array}$ & $\begin{array}{l}\text { Standard } \\
\text { anatomy }\end{array}$ & $5^{\circ}-40^{\circ}$ & $16 \%-41 \%$ & $28 \%-58 \%$ & $\begin{array}{l}\text { High } 5 \text { carbon sugars } \% \\
\text { Low } 6 \text { carbon sugar } \%\end{array}$ \\
\hline $\begin{array}{l}\text { Compression } \\
\text { wood }\end{array}$ & $\begin{array}{l}\text { Round } \\
\text { tracheids }\end{array}$ & $\begin{array}{l}30^{\circ}- \\
50^{\circ}\end{array}$ & $\begin{array}{l}5 \text { to } 10 \% \text { higher high } \\
\text { H/G }\end{array}$ & $\begin{array}{l}5 \text { to } 10 \% \text { lower cellulose } \\
\text { content, smaller fibril width }\end{array}$ & Higher galactose content \\
\hline Tension wood & $\begin{array}{l}\text { Often G-layer } \\
\text { fibres }\end{array}$ & $0^{\circ}-15^{\circ}$ & $\begin{array}{l}5 \text { to } 10 \% \text { lower high } \\
\text { S/G }\end{array}$ & $\begin{array}{l}5 \text { to } 10 \% \text { higher cellulose } \\
\text { content, larger fibril width }\end{array}$ & $\begin{array}{l}\text { Globally similar except for } \\
\text { G-layer }\end{array}$ \\
\hline
\end{tabular}

MFA: mean microfibril angle

\section{Posture control by maturation forces dissymmetry}

The primary function of force generation is the motor action for posture control of the slender wooden stem (Moulia et al 2019, Fournier et al 2013). Vertical growth is an unstable process: any small accidental rotation of the root system, or pruning of a lateral branch, results in a small trunk inclination and slightly oblique growth, that would rapidly diverge to high levels without a rapid counteracting action. Oblique growth, on the other hand, is very common for branches or the shoots of a coppice. Length and mass increase of the stem cause an increment of bending moment supported by the wooden cross section, leading to an increase of stem slope which needs to be actively counteracted through the generation of an opposite moment all along the stem (Alméras et al 2018a). This motor action is obtained by a dissymmetry of $F$ between upper and lower part of the stem. In the case of an accidentally inclined trunk, a higher-thanusual motor action is needed until it recovers verticality (Coutand et al 2007, Moulia \& Fournier 2009). In this case, RW is used on one side of the stem during all the process of verticality restoration while the opposite wood (OW) formed on the other side is similar to NW (Table 2).

Nearly always, there is a kind of pseudo-sinusoidal variation of $\alpha_{m}$. around the periphery of the trunk (Alméras et al 2005b, Ruelle et al 2011, Jullien et al 2013), even when there is no value indicating RW. In this case the difference between upper and lower face values is much lower (See Appendix 1 for beech and chestnut). When the active counter action needed for oblique growing is not too high (small trunk inclination), variations of $\alpha_{m}$ within NW, associated with eccentric growth, are enough: both "tensile" and "opposite" sides are NW. For oblique growing with higher inclination (as for many branches) and fast restoration of verticality, the use of RW is necessary (Yoshida et al 2000).

Table 2. Maturation strain ( $\alpha_{m}, \mu$ strain) for various trees restoring their verticality in French Guiana

\begin{tabular}{|c|c|c|c|c|c|}
\hline Tree & Family & Genus & Species & $\alpha_{m}$ TW & $\alpha_{m} \mathrm{OW}$ \\
\hline 1 & Annonaceae & Guatteria & schomburgkiana & 2130 & 1110 \\
\hline 2 & Annonaceae & Oxandra & asbeckii & 1950 & 310 \\
\hline 3 & Apocynaceae & Lacmellea & aculeata & 2580 & 120 \\
\hline 4 & Burseraceae & Protium & opacum & 2090 & 410 \\
\hline 5 & Chrysobalanaceae & Licania & membranacea & 3310 & 1180 \\
\hline 6 & Clusiaceae & Symphonia & globulifera & 2158 & 584 \\
\hline 7 & Flacourtiaceae & Casearia & javitensis & 3350 & 140 \\
\hline 8 & Goupiaceae & Goupia & glabra & 2350 & 770 \\
\hline 9 & Hugoniaceae & Hebepetalum & humiriifolium & 2890 & 650 \\
\hline 10 & Icacinaceae & Dendrobangia & boliviana & 2210 & 120 \\
\hline 11 & Lauraceae & Ocotea & indirectinervia & 2650 & 680 \\
\hline 12 & Lecythidaceae & Eschweilera & sagotiana & 2970 & 680 \\
\hline 13 & Lecythidaceae & Lecythis & poiteaui & 3000 & 760 \\
\hline 14 & Meliaceae & Trichilia & schomburgkii & 2780 & 680 \\
\hline 15 & Mimosaceae & Inga & marginata & 3010 & 680 \\
\hline 16 & Myrtaceae & Myrcia & decorticans & 2020 & 680 \\
\hline 17 & Papilionaceae & Ormosia & bolivarensis & 3260 & 1210 \\
\hline 18 & Papilionaceae & Ormosia & coutinhoi & 2780 & 1400 \\
\hline 19 & Rhizophoraceae & Cassipourea & guianensis & 2740 & 1220 \\
\hline 20 & Sapindaceae & Cupania & scrobiculata & 2710 & 770 \\
\hline 21 & Sapindaceae & Talisia & simaboides & 3470 & 1030 \\
\hline 22 & Caesalpiniaceae & Eperua & falcata & 1312 & 429 \\
\hline 23 & Caesalpiniaceae & Eperua & falcata & 2282 & 710 \\
\hline 24 & Caesalpiniaceae & Eperua & falcata & 2122 & 582 \\
\hline
\end{tabular}




\begin{tabular}{|l|l|l|l|l|l|}
$\mathbf{2 5}$ & Flacourtiaceae & Laetia & procera & 2912 & 416 \\
\hline 26 & Flacourtiaceae & Laetia & procera & 2701 & 666 \\
\hline 27 & Flacourtiaceae & Laetia & procera & 1590 & 582 \\
\hline 28 & Simaroubaceae & Simarouba & amara & 1648 & 426 \\
\hline 29 & Simaroubaceae & Simarouba & amara & 3219 & 179 \\
\hline 30 & Simaroubaceae & Simarouba & amara & 1616 & 502 \\
\hline 31 & Lauraceae & Ocotea & guyanensis & 2097 & 399 \\
\hline 32 & Lauraceae & Sextonia & rubra & 2362 & 328 \\
\hline 33 & Fabaceae & Inga & alba & 2408 & 310 \\
\hline 34 & Fabaceae & Tachigali & melinonii & 1488 & 480 \\
\hline 35 & Myristicaceae & Virola & michelii & 1708 & -45 \\
\hline 36 & Myristicaceae & Iryanthera & sagotiana & 1485 & -12 \\
\hline Mean & $\mathbf{2 1}$ families & $\mathbf{2 4}$ genera & $\mathbf{3 0}$ species & $\mathbf{2 4 2 7}$ & $\mathbf{5 8 7}$ \\
\hline Max & $\mathbf{2 2}$ families & $\mathbf{2 5}$ genera & $\mathbf{3 1}$ species & $\mathbf{3 4 7 0}$ & $\mathbf{1 4 0 0}$ \\
\hline Min & $\mathbf{2 3}$ families & $\mathbf{2 6}$ genera & $\mathbf{3 2}$ species & $\mathbf{1 3 1 2}$ & $\mathbf{- 4 5}$ \\
\hline
\end{tabular}

Tree 1 to 21: data from Clair et al 2006; tree 22 to 30: data from Ruelle et al 2011;

Tree 31 to 36: data from Chang et al 2009. Negative values correspond to compression stress

\section{Material and methods}

\section{Selection of standing trees}

On the basis of experimental campaigns conducted up to 2001 it appeared that the main source of variation of $\alpha_{m}$ was the mechanical adaption of the tree to requirements of growth. Apart from the difference between softwoods and hardwoods for RW, no clear difference was found between species; however, the diversity of studied species was not so high. In order to observe a wider diversity of species, 11 trees were selected in a tropical rain forest of French Guiana with the help of the botanical expert M.F. Prévost, each from a different family - one tree per species and one species per family. 3 poplar trees and 3 conifer trees (spruce and pines) from temperate forest in France and China were added to the sampling to widen the selection (Table 3).

For the spruce tree, two logs, corresponding to two GSI measurement levels (see below), were used, at $1 \mathrm{~m}$ distance from each other. The objective was not to obtain a mean value or a range of values per species or family for biomechanical parameters such as $\alpha_{m}$, but to investigate the links between maturation forces and wood properties, with the hypothesis that each measurement point is representative of wood maturation.

Table 3. Trees used in the study.

\begin{tabular}{|l|l|l|l|l|}
\hline Family & Genus & Species & $D B H$ & RW \\
\hline Melastomataceae & Miconia & fragilis & 23.6 & GL \\
\hline Meliaceae & Carapa & procera & 23.4 & GL. \\
\hline Lecythidaceae & Eschweilera & decolorens & 23.8 & LGL \\
\hline Vochysiaceae & Qualea & rosea & 30.3 & LGL \\
\hline Cecropiaceae & Cecropia & sciadophylla & 25.3 & GL \\
\hline Lauraceae & Ocotea & guyanensis & 30.9 & GL. \\
\hline Flacouritaceae & Laetia & procera & 29.4 & GLc. \\
\hline Bignonaceae & Jacaranda & copaïa & 21.7 & NGL \\
\hline Myristiceceae & Virola & surinamensis & 20.4 & NGL. \\
\hline Cesalpinaceae & Eperua & falcata & 27.9 & GL. \\
\hline Simaroubaceae & Simaruba & amara & 27.7 & NGL. \\
\hline Salicaceae & Populus & hybrid & 38.3 & GL \\
\hline Salicaceae & Populus & hybrid & 34.8 & GL \\
\hline Salicaceae & Populus & hybrid & 25.4 & GL \\
\hline Pinaceae & Picea & abies & 24.9 & CW \\
\hline Pinaceae & Picea & abies & 24.9 & CW \\
\hline Pinaceae & Pinus & pinaster & 20.1 & CW \\
\hline Pinaceae & Pinus & sylvestris & 23 & CW \\
\hline Mean & & & 26.43 & \\
\hline
\end{tabular}

$D B H$ : tree diameter at breast height in cm; RW: reaction wood type (from Ghislain \& Clair 2017): GL: tension wood (TW) with gelatinous layer; LGL: TW with lignified G layer, GLc: TW with multilayer G layer; NGL: TW with no G layer; CW:

compression wood 
Rather small diameter trees exhibiting a common type of bottom geometry with a basal curvature were chosen (Fig. 2). Small diameter trees are more efficient in restoring verticality; they have been selected to have a sufficient thickness (more than $25 \mathrm{~mm}$ ) of reaction wood in the upper or lower part of the trunk, just above the curvature, in order to cut material for lab tests. The diameter at breast height of the 17 trees did not exceed $40 \mathrm{~cm}$ and the mean was 26.4 .

\section{In situ measurements of maturation strain}

The single-hole method developed in CIRAD (https://www.cirad.fr/) was used. Two pins are inserted in the trunk surface in longitudinal alignment $45 \mathrm{~mm}$ from each other (Jullien et al 2013). This distance is measured with a linear displacement transducer before and after drilling a hole of diameter $20 \mathrm{~mm}$ and depth about $20 \mathrm{~mm}$ in the middle between the two pins. The difference in $\mu \mathrm{m}$ between after and before drilling is called growth stress indicator (GSI); it is positive for a tension force and negative for a compression force. Eight GSI measurements are performed on each tree or tree level, equally spaced around the circumference, beginning on the top of the inclined trunk for hardwoods, where TW is expected, or on the bottom for softwoods, where $\mathrm{CW}$ is expected.

$G S /$ is theoretically (Archer 1984) related to maturation strain $\left(\alpha_{m}\right)$ by the relationship:

$$
\alpha_{m}=\phi . G S I, \alpha_{m} \text { in microstrain }\left(\mu \varepsilon=10^{-6}\right), G S I \text { in } \mu \mathrm{m}, \phi \text { in } \mu \varepsilon / \mu \mathrm{m}
$$

where the calibration factor $\phi$ is calculated by modelling the drilling of an anisotropic material occupying a half plane, though a complex equation using wood elastic constants and geometrical factors (distance between pins and hole diameter), see Appendix 2.

\section{Wood specimens for physical and mechanical properties measurements.}

Just after cutting each tree, a disk ( $2 \mathrm{~cm}$ thick) was crosscut at the level of GSI measurements (Fig. 2). Distance from pith to bark $\left(D P_{x}\right)$ for each $G S I$ measurement position was measured. Eight longitudinally oriented rods were sawn just above the disk, at the $8 \mathrm{GSI}$ positions, the closest possible to the bark, a few days after tree felling, in a local workshop. The dimensions of the rods were $500 \mathrm{~mm}$ ( $L$, longitudinal direction) $\times 25 \mathrm{~mm}$ ( $R$, radial direction) $\times 25 \mathrm{~mm}(T$, tangential direction) and they were kept in the green state, wrapped in food-grade transparent cellophane, until the measurement of green $\mathrm{MOE}\left(E_{g}\right)$. A total of 144 rods were prepared.

A smaller rod ( $50 \mathrm{~mm} \times 25 \mathrm{~mm} \times 25 \mathrm{~mm}$ ) was cut from these long rods for shrinkage measurement after $E_{g}$ measurement. 


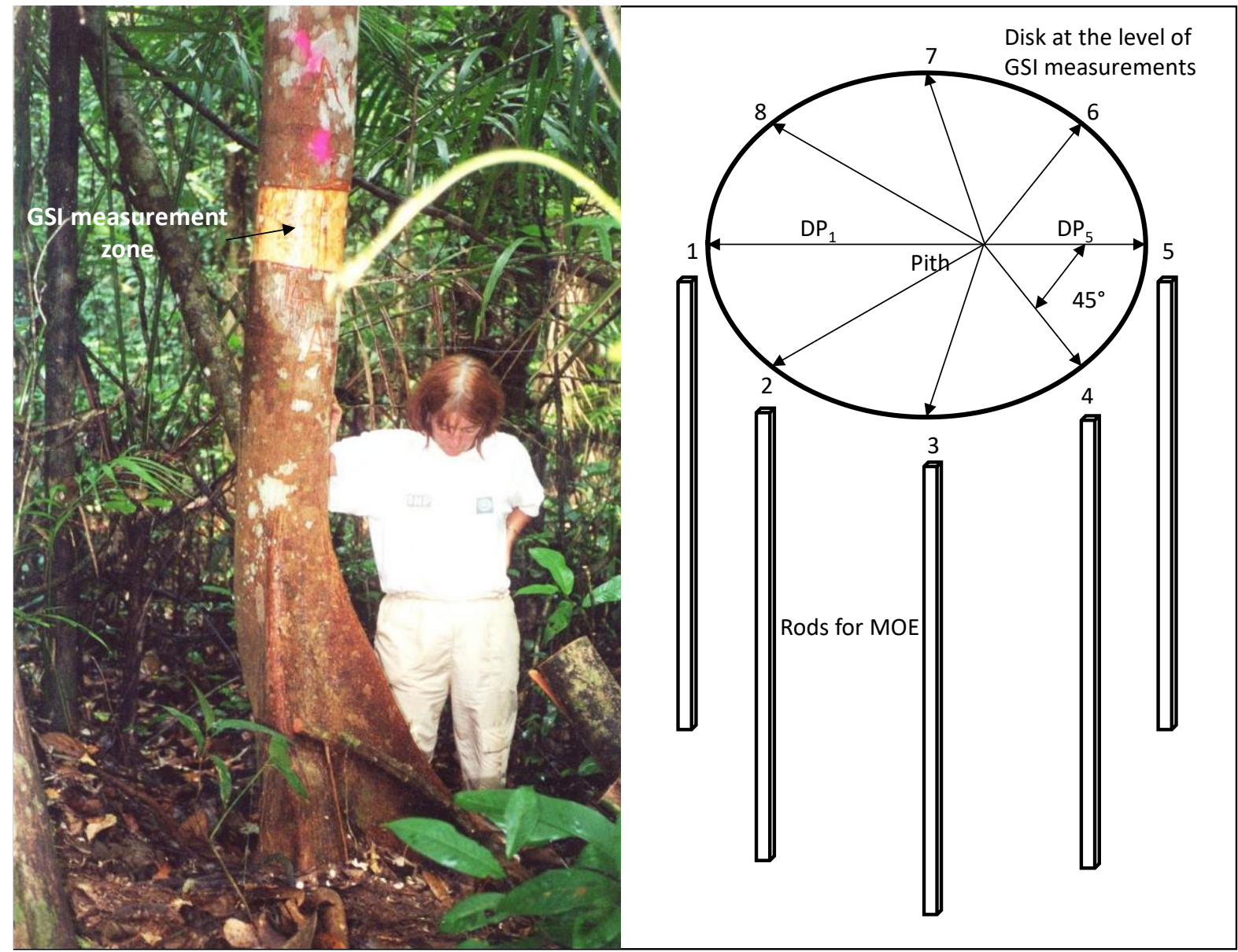

Figure 2. Tree measured in French Guiana, wooden disk and rods sawn for each tree $D P_{x}$ : distance to pith from the $x$ GSI point

The remaining long rods $(430 \mathrm{~mm} \times 25 \mathrm{~mm} \times 25 \mathrm{~mm})$ were air dried in the conditioning chamber at 65 $\%$ air relative humidity $(\mathrm{RH})$ and $20^{\circ} \mathrm{C}$ temperature until equilibrium, corresponding to wood moisture content (MC) around $13 \%$. The MOE was again measured on the air-dry rods as such, giving a "crude" airdry MOE. Rods were then planed on all four sides to get standard air-dry rods $(400 \mathrm{~mm} \times 20 \mathrm{~mm} \times 20 \mathrm{~mm}$ ) and standard air-dry $\operatorname{MOE}\left(E_{d}\right)$ was measured again.

\section{Modulus of elasticity}

The flexure free-free vibration method analysed with the Timoshenko model (Bordonné 1989, Brancheriau \& Baillères 2002) was used for all measurements. Dimensions in the 3 directions $(L, R, T)$ and mass $(M)$ of the rods were measured with a high precision (at least $0.1 \%$ ) using a precision balance and digital calipers. The rod was put on 2 thin wires at the positions of first vibration mode nodes and tapped at one end, successively on the radial (TL) and tangential (RL) face, corresponding to the RL and TL hitting plane, respectively. The resonant frequency $f_{i}$ was measured for the three first vibration modes $\left(f_{1}, f_{2}, f_{3}\right)$. Using the approximate solution of free vibration theory of Timoshenko, Bordonné (1989) proved that two useful variables $x_{i}$ and $y_{i}$ can be built from $f_{i}$ frequencies, theoretically linked by the expression:

$$
y_{i}=E / \rho-x_{i} . E /(k . G)
$$

where $E$ is the longitudinal modulus of elasticity (MOE) of the rod, $G$ the shear modulus in the hitting plane ( $G_{T L}$ or $G_{R L}$, depending on the orientation of the rod on the wires), $\rho$ the rod density and $k$ a fixed factor. The 3 frequencies $\left(f_{1}, f_{2}, f_{3}\right)$ give 3 points of coordinates $\left(x_{i}, y_{i}\right)$ allowing fitting of a straight line with a regression coefficient that should be very close to 1.0. The slope, the most sensitive to defects, and the intercept of the regression line are $-E /(k . G)$ and $E / \rho$, respectively. $E / \rho$ is the specific modulus $(S M)$ and 
equals the square of sound speed in the $L$ direction (unit $\left.\mathrm{m}^{2} / \mathrm{s}^{2}\right)$ while the ratio $E / G\left(E_{L} / G_{T L}\right.$ or $\left.E_{L} / G_{R L}\right)$ describes elastic anisotropy and is useful for the calculation of $\phi$. Density is calculated as mass to volume ratio $\rho=M /(L . R . T)$ and MOE by the formula $E=S M$. $\rho$. Then $G$ can be derived from $E$ and $E / k . G$, with $k=5 / 6$ for this geometry (Brancheriau \& Baillères 2002). For some sample, measurements with a regression coefficient below 0.98 , the values for $G_{T L}$ or $G_{R L}$ were not considered.

Due to the viscoelastic nature of wood and the smaller measurement times involved, the dynamic modulus obtained using vibration method is expected to be higher than the quasi-static modulus that would be more appropriate to analyse GSI measurements performed within a few minutes. It is, however, very well correlated and proportional to the quasi-static modulus obtained in 4 points bending, with a relative difference of only $4 \%$ (Brancheriau \& Baillères 2002).

\section{Maturation stresses}

The peripheral maturation stresses $\left(\sigma_{m}\right)$ is calculated as the product of $\alpha_{m}$ and green $\operatorname{MOE}\left(E_{g}\right)$.

\section{Basic density and shrinkage measurements.}

For each small rod, mass $(M)$, volume $(V)$ and longitudinal dimension $(L)$ were measured in the green state $\left(M_{\mathrm{g}}, V_{\mathrm{g}}, L_{\mathrm{g}}\right)$ and in the anhydrous state $\left(M_{0}, V_{0}, L_{0}\right)$. From these values basic density $(B D)$, volumetric shrinkage (VS) and longitudinal shrinkage (LS) were calculated as follows:

$$
\begin{aligned}
& B D=M_{0} / V_{g} \\
& V S=\left(V_{g}-V_{0}\right) / V_{0} \\
& L S=\left(L_{g}-L_{0}\right) / L_{0}
\end{aligned}
$$

\section{Anatomical observations}

On 2 selected positions on the two sides of the tree, anatomical observations were performed (Ruelle 2003). Anatomical sections ( $15 \mu \mathrm{m}$ thickness) were cut on a microtome (Leitz, Oberkochen, Germany, model 1512, with feather knifes) in the central zone of a shrinkage specimen. They were stained with a double coloration safranin/alcian-blue. Lignified cell walls have a red colour while pure cellulosic G-layers have a blue colour. Sections were observed with a light microscope (Olympus, Hamburg, Germany, BX60) and pictures were taken with a digital camera (Nikon, Tokyo, Japan, Coolpix 4500) with good definition (pixel density: $2272 \times 1704$ ) and a magnification factor of 100. A higher magnification factor (500) was used to measure micro-fibril angles for softwood species (Senft \& Bendtsen 1985).

\section{Results}

\section{Relationships between green and dry properties}

Concerning the green state, $M C_{g}$ was on average $89 \%$, ranging from $38 \%$ to $182 \%$ (39\% to $155 \%$ as a tree average) and was strongly dependent on wood density. The air-dry state, here, refers to the condition of the specimens after a long storage in a room controlled for temperature $\left(T=20^{\circ} \mathrm{C}\right)$ and air relative humidity $(R H=65 \%)$. The corresponding equilibrium $M C\left(M C_{d}\right)$ ranged from $12 \%$ to $16 \%$ depending on the species and wood type within the species.

A proportional relationship, with a very high coefficient of determination, was observed between $B D$ and air-dry density $(D D)$ for this sampling (Fig. 3). The proportionality coefficient $(B D / D D)$ had a mean of 0.826 , very similar to the result of Vieilledent et al (2018) and ranged from 0.77 to 0.86 . It depended mainly on the total volumetric shrinkage (VS) (Fig. 4).

For MOE $(E)$, specific modulus $(S M)$ and shear moduli $\left(G_{T L}\right.$ and $\left.G_{R L}\right)$, there are also proportional relationships between green and dry values. The determination coefficient $\left(\mathrm{R}^{2}\right)$ is very high for $E$ and $S M$ (Fig. 5) and the influence of $M C$ is relatively small (around $10 \%$ decrease from air-dry to green state).

In the case of shear moduli, the proportional relationship is the same for the two directions (TL and RL) with a lower $R^{2}$, mostly due to the much higher sensitivity of $E / G$ (where $G$ stands for either $G_{T L}$ or $G_{R L}$ ) to small heterogeneities along the rod (Fig. 6). MC influence is higher (around $25 \%$ decrease from dry to green state). 
Calibration factor for maturation strains

The calibration factor $\phi$ can be calculated using the regression found in Appendix $\mathbf{2}$ for all positions where $E_{L} / G_{T L}$ is available at the green state:

(8)

$$
\phi=-7.57 . \operatorname{Ln}\left(E_{L g} / G_{T L g}\right)+34.665
$$

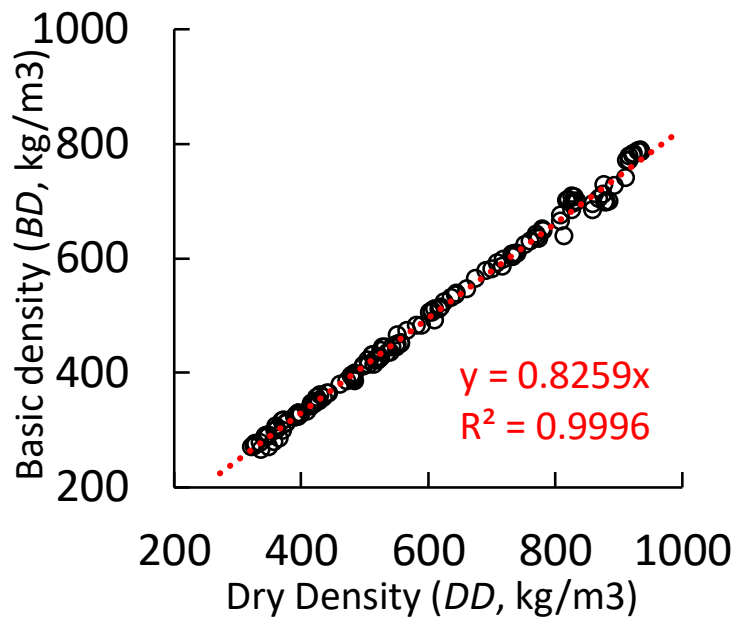

Figure 3. Proportional relationship between dry and basic density

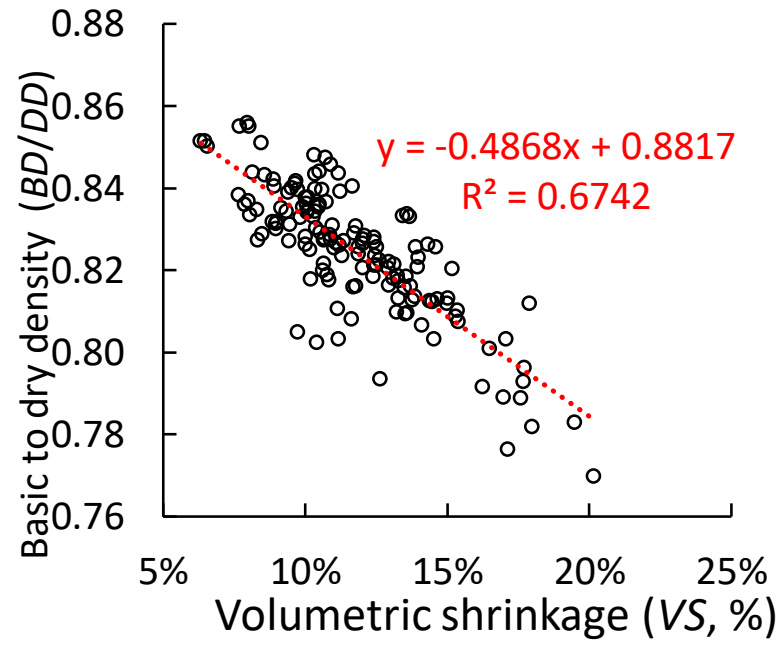

Figure 4. Dependence of the basic to dry density ratio on the total volumetric shrinkage.

There was a very good exponential relationship between $E_{L} / G_{T L}$ and basic specific modulus $\left(S M_{b}\right)$, for all positions (Fig. 7). 


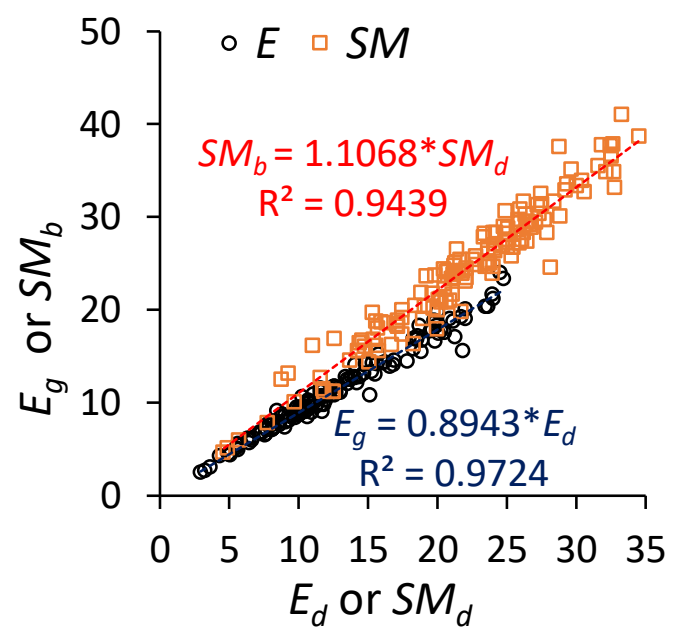

Figure 5. Proportional relationship between air-dry and green values for longitudinal modulus of elasticity (MOE) and specific modulus; $E$ : MOE (GPa); SM: specific modulus $\left(\mathrm{Mm}^{2} / \mathrm{s}^{2}\right) ; E_{g}$ : green MOE; $E_{d}$ : dry MOE; $S M_{b}$ : basic $S M ; S M_{d}$ : dry $S M$.

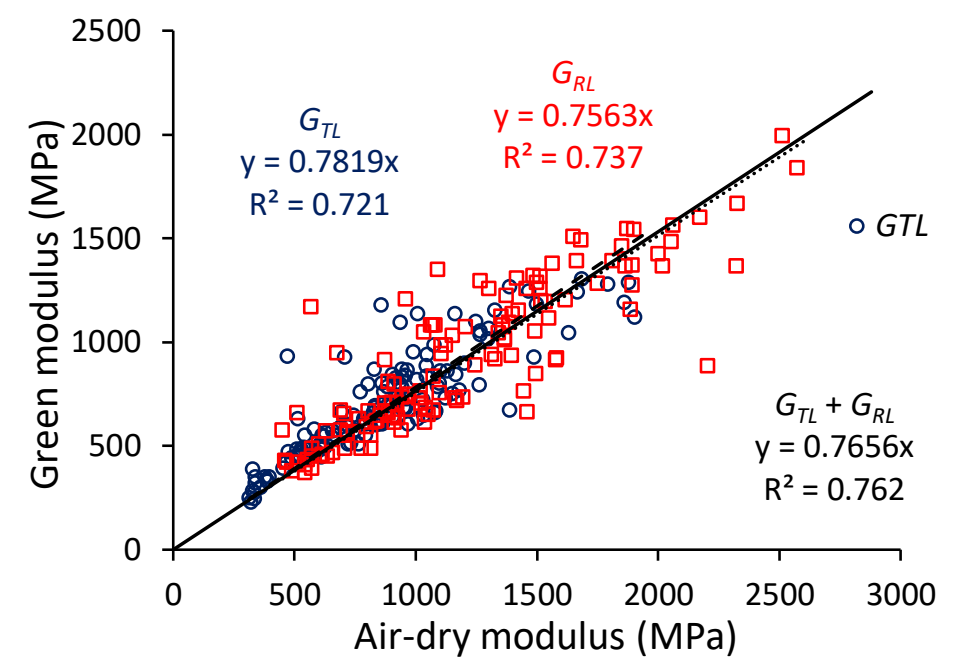

Figure 6. Proportional relationship between air-dry and green shear moduli

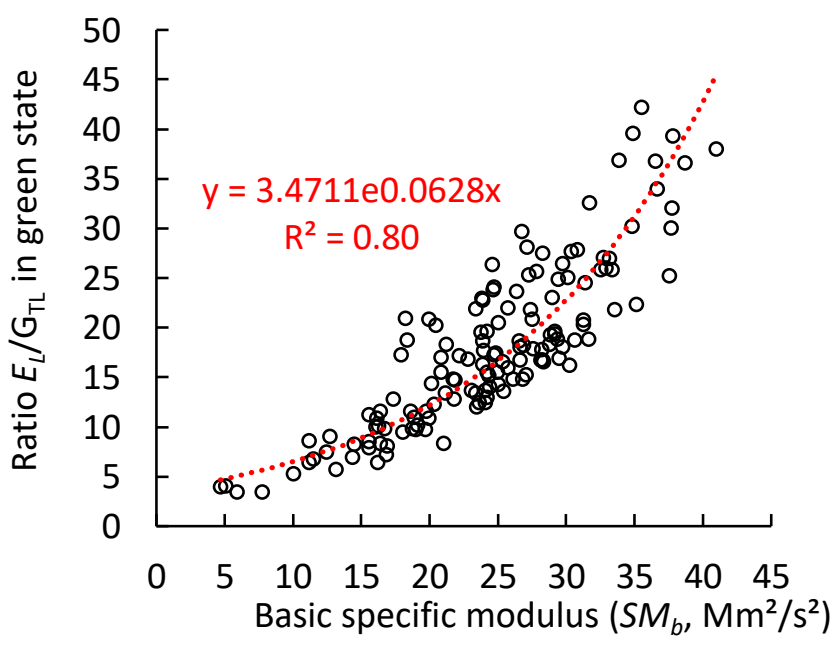

Figure 7. Relationship between $E_{L} / G_{T L}$ and basic specific modulus $\left(S M_{b}\right)$ 
Using this exponential formula in the equation for the calibration factor $\phi$, we find a linear relationship between $\phi$ and $S M_{b}$ :

$$
\phi\left(S M_{b}\right)=-0.475 \cdot S M_{b}+25.24
$$

with the same regression factor $\left(R^{2}=0.80\right)$. Considering that $S M_{b}$ is more easily and more precisely measured, we have decided to use this relationship for the calibration factor calculation in the data sheet.

\section{Peripheral maturation stress and GSI within a tree}

In the first sheet of the accompanying data file (see $\S$ "Data accessibility" below), tree-by-tree graphs are drawn showing the relationship between $G S I$ and $\sigma_{m}$ for each tree. For each tree there are 8 pairs of $G S I-\sigma_{m}$ measurements, yielding a proportional relationship with a very high $R^{2}$ level (all $R^{2}>0.97$ and $72 \%$ of $R^{2}$ values $>0.99$ ). This result suggests that it is perfectly suitable to use $G S I$ as a proxy for $\sigma_{m}$ at tree level for biomechanics studies. The conversion factor $\psi=\sigma_{m} / G S I$ (in $\mathrm{MPa} / \mu \mathrm{m}$ ) ranged from 0.064 to 0.259 depending on the species (Table 4).

Table 4. Mean values of parameters per tree.

\begin{tabular}{|l|l|l|l|l|l|l|}
\hline Genus & Species & $B D$ & $S M_{b}$ & $E_{g}$ & $\psi$ & $\mathrm{R}^{2}$ \\
\hline Miconia & fragilis & 0.71 & 26.92 & 19.0 & 0.232 & 0.9997 \\
\hline Carapa & procera & 0.61 & 24.87 & 15.2 & 0.203 & 0.9941 \\
\hline Eschweilera & decolorens & 0.78 & 25.92 & 20.2 & 0.259 & 0.9996 \\
\hline Qualea & rosea & 0.56 & 21.29 & 12.1 & 0.199 & 0.9936 \\
\hline Cecropia & sciadophylla & 0.35 & 34.95 & 12.3 & 0.107 & 0.9788 \\
\hline Ocotea & guyanensis & 0.46 & 27.20 & 12.7 & 0.156 & 0.9903 \\
\hline Laetia & procera & 0.66 & 21.97 & 14.4 & 0.218 & 0.9979 \\
\hline Jacaranda & copaïa & 0.42 & 22.14 & 9.2 & 0.132 & 0.9916 \\
\hline Virola & surinamensis & 0.29 & 36.89 & 10.8 & 0.084 & 0.9954 \\
\hline Eperua & falcata & 0.70 & 22.99 & 16.1 & 0.234 & 0.9975 \\
\hline Simaruba & amara & 0.30 & 28.40 & 8.4 & 0.096 & 0.9976 \\
\hline Populus & hybrid & 0.29 & 28.04 & 8.2 & 0.110 & 0.9724 \\
\hline Populus & hybrid & 0.34 & 29.19 & 9.8 & 0.114 & 0.9903 \\
\hline Populus & hybrid & 0.38 & 19.37 & 7.4 & 0.128 & 0.9823 \\
\hline Picea & abies & 0.51 & 20.61 & 10.0 & 0.152 & 0.9933 \\
\hline Picea & abies & 0.49 & 18.10 & 8.4 & 0.142 & 0.9989 \\
\hline Pinus & pinaster & 0.42 & 10.68 & 11.4 & 0.064 & 0.9793 \\
\hline Pinus & sylvestris & 0.45 & 15.88 & 4.1 & 0.108 & 0.9882 \\
\hline
\end{tabular}

$B D$ : basic density $\left(\mathrm{Kg} / \mathrm{dm}^{3}\right) ; \mathrm{SM}_{b}$ : basic specific modulus $\left(\mathrm{Mm}^{2} / \mathrm{s}^{2}\right) ; E_{\mathrm{g}}$ : green elastic modulus (GPa); $\psi$ : conversion coefficient for maturation stress (in $\mathrm{MPa} / \mu \mathrm{m}$ ); $\mathrm{R}^{2}$ regression coefficient of the proportional relationship between $\sigma_{m}$ and GSI within the tree.

\section{Force generation and longitudinal wood properties}

The initial or peripheral maturation stress $\sigma_{m}$ is the force created by the living wood per unit surface. It is the product of the maturation strain $\left(\alpha_{m}\right)$ and the green L MOE $\left(E_{g}\right)$, itself the product of $B D$ and $S M_{b}$. $B D, S M_{b}$ and $\alpha_{m}$ are the parameters resulting from the development of the living wood until cell death

A correlation analysis (Table 5) shows that $\sigma_{m}$ is mostly dependent on $\alpha_{m}\left(\mathrm{R}^{2}=88 \%\right)$ then on $S M_{b}(22 \%)$ and on $B D(8 \%)$. Moreover, the three parameters $S M_{b}, E_{g} / G_{T L g}, E_{g} / G_{R L g}$ are very strongly correlated. They are all indicators of wood anisotropy.

The correlation between $L S$ and $\alpha_{m}$ is weak when all species are considered. This is not true when separating hardwoods and softwoods (Fig. 8).

For each tree the angular variation around the perimeter of $\alpha_{m}$ and $L S$, in order to visualize their relationships at the same position, is also given in the accompanying data file (see $\S$ "Data accessibility" below). Globally, there is a clear association between zones with high and low levels of each parameter. Tree by tree, the peak value (maximum in absolute value) is a rather narrow zone and there is often an angular shift between $\alpha_{m}$ and $L S$ which are not exactly measured at the same position. This explains why, besides the high similarity between profiles of the two parameters, regression coefficients $\left(R^{2}\right)$ are not so high (Fig. 8). 
Table 5. Correlation (Spearman) coefficients between parameters.

\begin{tabular}{|l|l|l|l|l|l|l|l|l|l|l|}
\hline & $\alpha_{m}$ & $\sigma_{m}$ & $B D$ & $S M_{b}$ & $L S$ & $E_{g}$ & $G_{T L g}$ & $G_{R L g}$ & $E_{L} / G_{T L g}$ & $E_{L} / G_{R L g}$ \\
\hline$\alpha_{m}$ & $\mathbf{1}$ & $\mathbf{0 . 9 4 1}$ & 0.095 & $\mathbf{0 . 3 8 1}$ & 0.196 & $\mathbf{0 . 4 3 5}$ & -0.049 & -0.047 & $\mathbf{0 . 4 3 1}$ & $\mathbf{0 . 4 2 2}$ \\
\hline$\sigma_{m}$ & $* * *$ & $\mathbf{1}$ & $\mathbf{0 . 2 9 0}$ & $\mathbf{0 . 4 6 7}$ & 0.137 & $\mathbf{0 . 6 8 5}$ & 0.059 & 0.058 & $\mathbf{0 . 5 5 9}$ & $\mathbf{0 . 4 9 5}$ \\
\hline$B D$ & & $* * *$ & $\mathbf{1}$ & $\mathbf{- 0 . 3 4 6}$ & 0.196 & $\mathbf{0 . 5 9 3}$ & $\mathbf{0 . 7 9 0}$ & $\mathbf{0 . 7 8 3}$ & -0.094 & -0.178 \\
\hline$S M_{b}$ & $* * *$ & $* * *$ & $* * *$ & $\mathbf{1}$ & -0.189 & $\mathbf{0 . 5 0 0}$ & $\mathbf{- 0 . 4 9 9}$ & $\mathbf{- 0 . 5 0 8}$ & $\mathbf{0 . 8 4 3}$ & $\mathbf{0 . 8 2 8}$ \\
\hline$L S$ & $*$ & & $*$ & $*$ & $\mathbf{1}$ & -0.074 & 0.271 & 0.277 & -0.231 & -0.175 \\
\hline$E_{g}$ & $* * *$ & $* * *$ & $* * *$ & $* * *$ & & $\mathbf{1}$ & $\mathbf{0 . 2 8 9}$ & 0.255 & $\mathbf{0 . 6 1 9}$ & $\mathbf{0 . 5 3 4}$ \\
\hline$G_{T L g}$ & & & $* * *$ & $* * *$ & $* *$ & $* * *$ & $\mathbf{1}$ & $\mathbf{0 . 8 6 6}$ & $\mathbf{- 0 . 5 1 6}$ & $\mathbf{- 0 . 4 7 3}$ \\
\hline$G_{R L g}$ & & & $* * *$ & $* * *$ & $* *$ & $* *$ & $* * *$ & $\mathbf{1}$ & $\mathbf{- 0 . 4 2 1}$ & $\mathbf{- 0 . 5 8 7}$ \\
\hline$E_{L} / G_{T L g}$ & $* * *$ & $* * *$ & & $* * *$ & $* *$ & $* * *$ & $* * *$ & $* * *$ & $\mathbf{1}$ & $\mathbf{0 . 8 7 7}$ \\
\hline$E_{L} / G_{R L g}$ & $* * *$ & $* * *$ & $*$ & $* * *$ & $*$ & $* * *$ & $* * *$ & $* * *$ & $* * *$ & $\mathbf{1}$ \\
\hline
\end{tabular}

Bold characters: correlation significant at $0.001 ;{ }^{* * *}$ : correlation significant at 0.001

**: correlation significant at $0.01 ; *$ : correlation significant at 0.05

$\alpha_{m}$ : maturation strain; $\sigma_{m}$ : maturation stress; $\phi$ and $\psi$ : conversion coefficients between GSI and maturation strain and stress, respectively; $B D$ : basic density (anhydrous mass/green volume); $L S$ : total longitudinal shrinkage; $E_{g}$ : green longitudinal elastic modulus; $G_{T L g}$ and $G_{R L g}$ : green $T L$ and RL shear modulus, respectively; $S M_{b}$ : basic specific modulus (green longitudinal elastic modulus/basic density); $E_{g} / G_{T L g}$ and $E_{g} / G_{R L g}$ : anisotropy ratio in green condition in TL and RL plane, respectively.

In order to have a global look on the parallelism between both variations, a "mean hardwood tree" and a "mean softwood tree" were calculated using the average of all hardwoods and all softwoods for ?m and LS (Fig. 9).

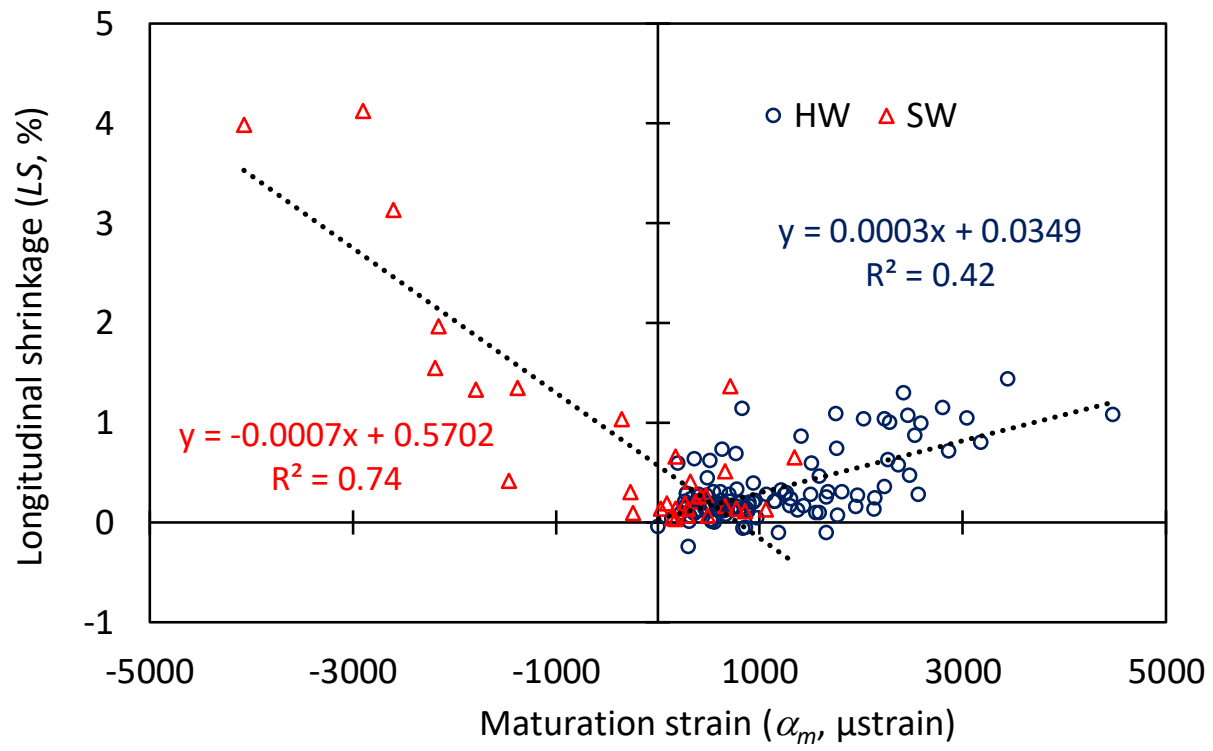

Figure 8. Relationships between longitudinal shrinkage and maturation strain $L S$ : longitudinal shrinkage; $\alpha_{m}$ : maturation strain; HW: hardwoods; SW: softwoods

These figures highlight the great similarity between maturation shrinkage $\left(\alpha_{m}\right)$ and hygroscopic shrinkage in the $L$ direction $(L S)$ for hardwoods. For softwoods high shrinkage is associated with negative $\alpha_{m}$. A very high similarity is found when using absolute values of $\alpha_{m}$ (Fig. 10). In these graphs, the same scale has been used for $\alpha_{m}$ and for $L S$ divided by an ad-hoc value, both being given in $\mu$ strain. 

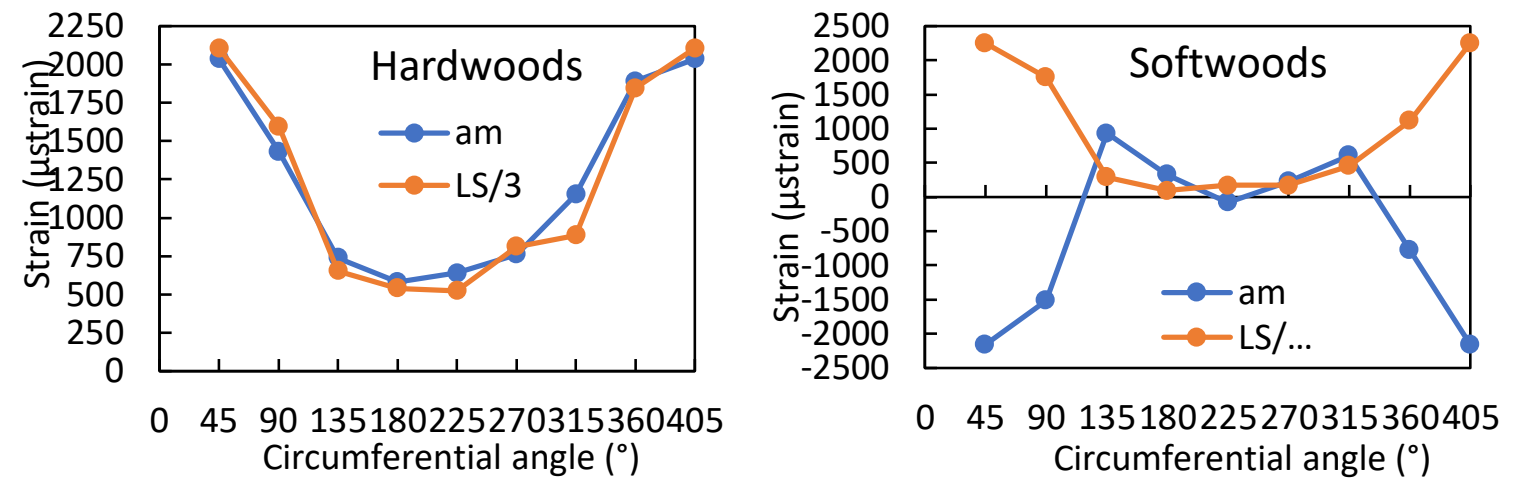

Figure 9. Circumferential variations for hardwoods (left) and softwoods (right) Mean value for all trees around the circumference, of maturation strain (am) and longitudinal shrinkage (LS). Angle: angular position of the 8 measurements (degree). The angular position was shifted $\left(+225^{\circ}\right)$ in order to have the expected reaction wood position in the middle of the profile.

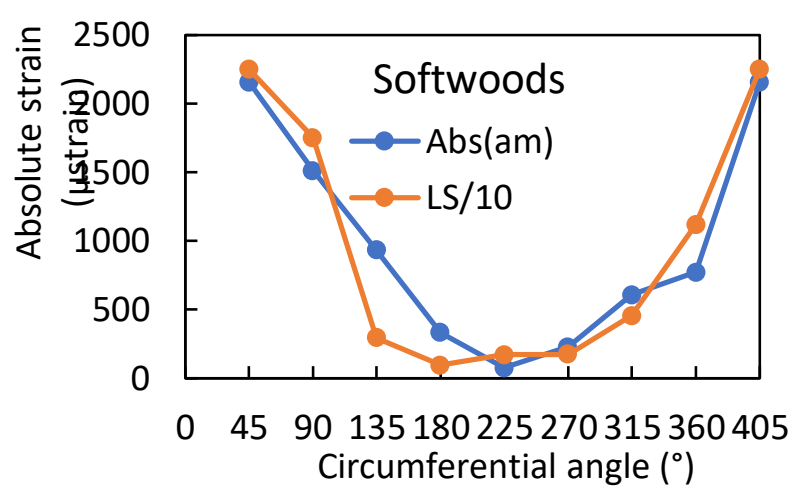

Figure 10. Circumferential variations for softwoods using absolute values for maturation strain. Same legend as Fig. 9

\section{Specific behaviour of reaction wood}

Maturation strain values, longitudinal shrinkage of the associated rods, together with visual observation of the wood disks for softwoods (Fig. 11), allowed allocation of a wood type to each tested specimen: $1=\mathrm{CW}, 2=$ both $\mathrm{CW}$ and NW, $3=\mathrm{NW}, 4=$ both NW and TW, $5=\mathrm{TW}$. Transverse sections $15 \mu \mathrm{m}$ thick cut from two NW and two RW rods were used to examine wood anatomy (Fig. 12 and Fig.13). 


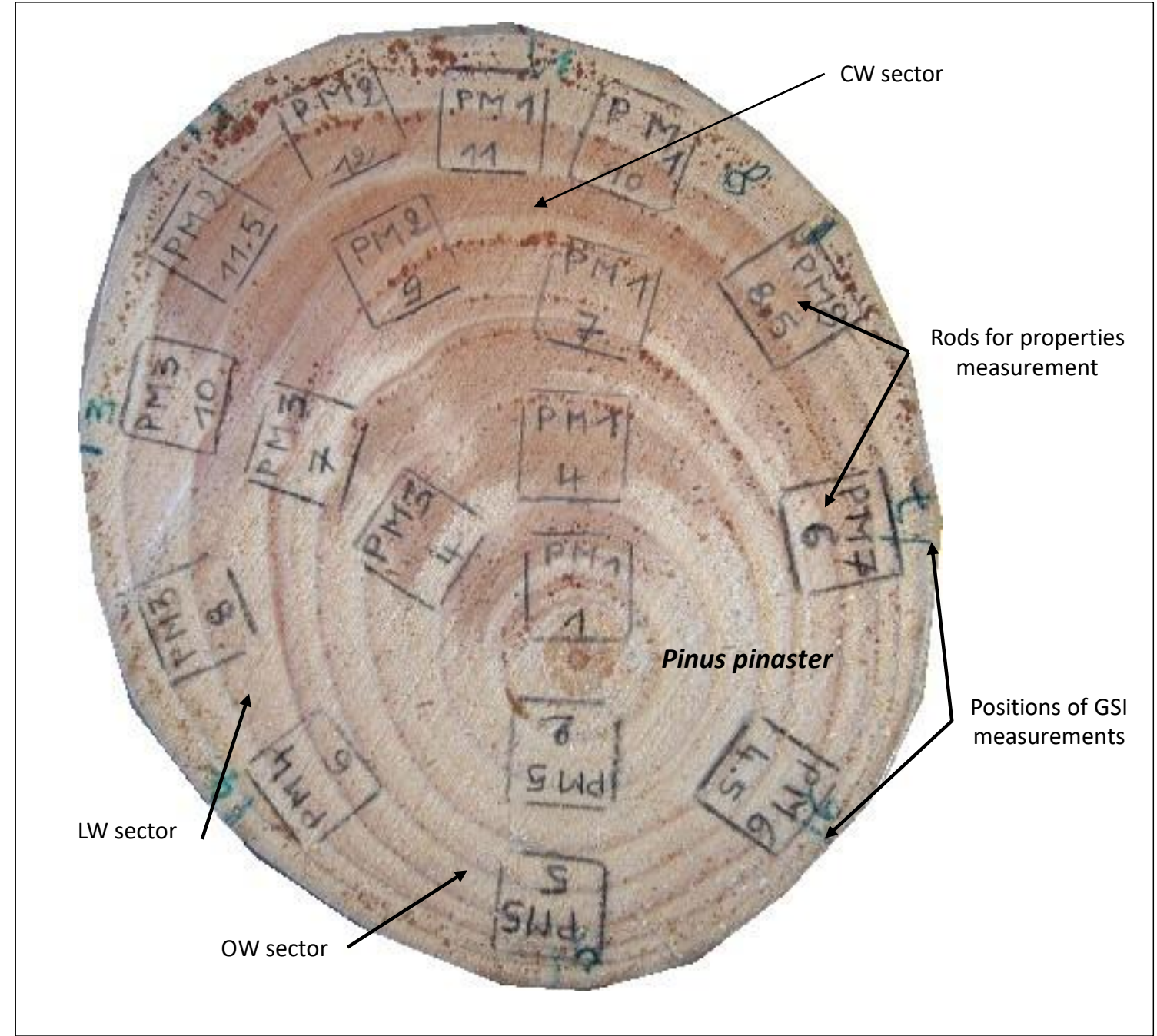

Figure 11. Image of the section of Pinus pinaster tree with the positions of measurements CW: compression wood, OW: opposite wood, LW: lateral wood

The mean microfibril angle (MFA) was measured for the conifer specimens only (Brémaud et al 2013). It is always high for $\mathrm{CW}$, and globally lower for NW but with some overlap around $30-35^{\circ}$. The 3 conifer trees were rather young (between 10 and 15 years old) so most of the NW can be considered as juvenile wood (Fig. 11). 

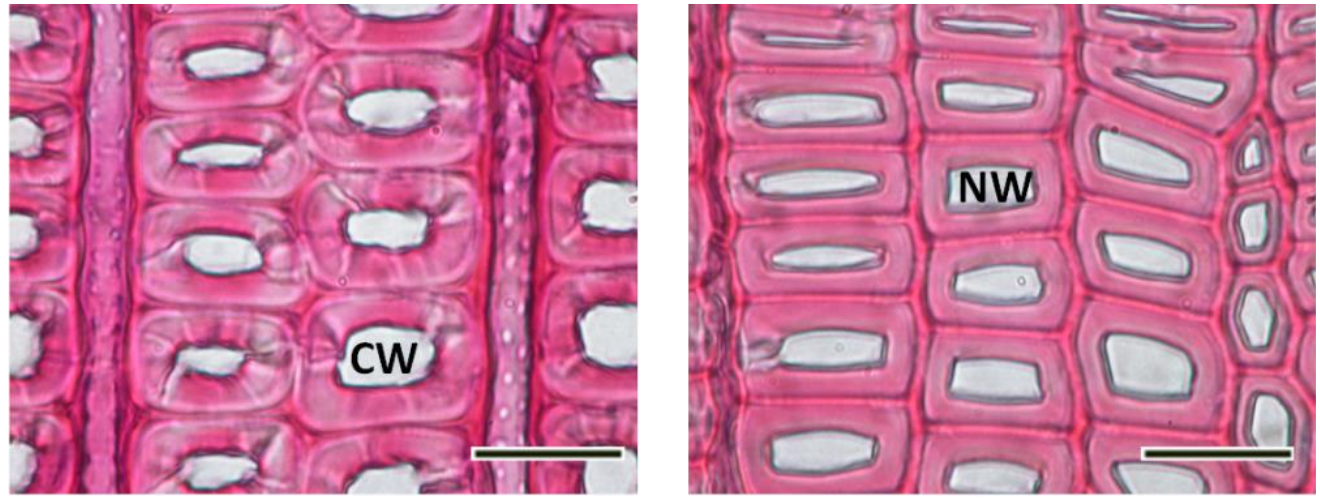

Picea abies; Scale bar: $25 \mu \mathrm{m}$
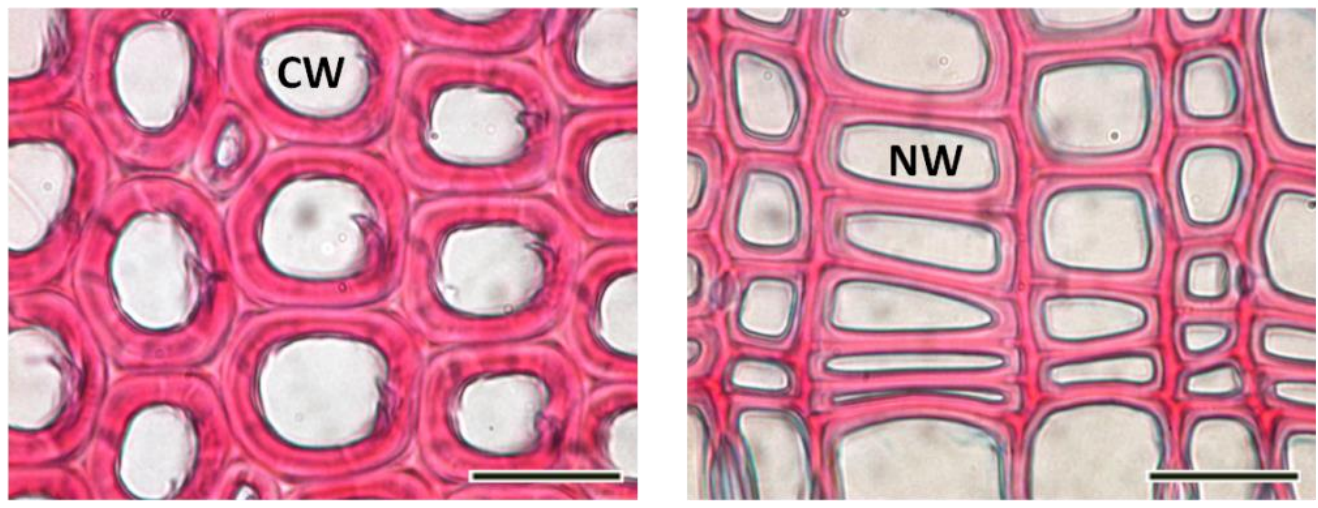

Pinus sylvestris; Scale bar: $25 \mu \mathrm{m}$
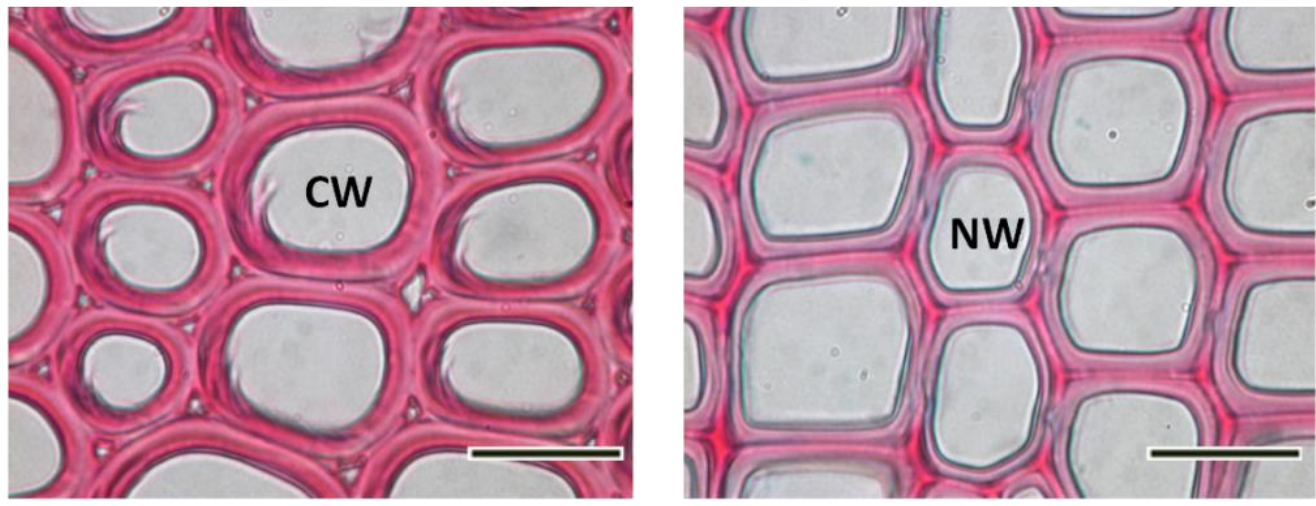

Pinus pinaster; Scale bar: $25 \mu \mathrm{m}$

Figure 12. Comparative anatomy of compression wood and normal wood for the conifer species CW: compression wood; NW: normal wood

For hardwoods, a majority of G-layer type TW (3 poplars, Miconia, Carapa, Ocotea, Cecropia, Eperua) were studied (Table 3), two species had a lignified G layer (Eschweilera \& Qualea), one a peculiar multilayered G layer (Laetia) and three no G layer fibre (Jacaranda, Virola, Simarouba), according to a recent classification based on 242 tropical species (Ghislain et al 2019). Measurement of MFA on the 3 species represented in Fig. 13 (Ruelle et al 2007) showed lower values for TW $\left(2^{\circ}\right.$ to $\left.14^{\circ}\right)$ than for NW $\left(10^{\circ}\right.$ to $\left.35^{\circ}\right)$, with some overlap around $10^{\circ}-14^{\circ}$. One clear indication within each tree is the much higher $L S$ for both RW types as compared to NW (Table 6). 

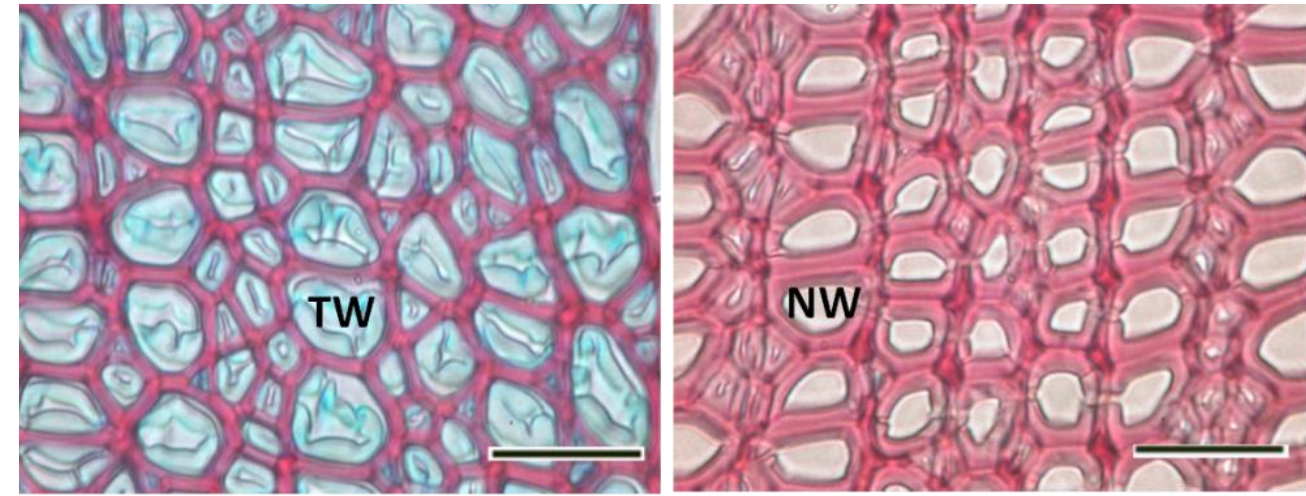

Eperua falcata; Scale bar: $25 \mu \mathrm{m}$
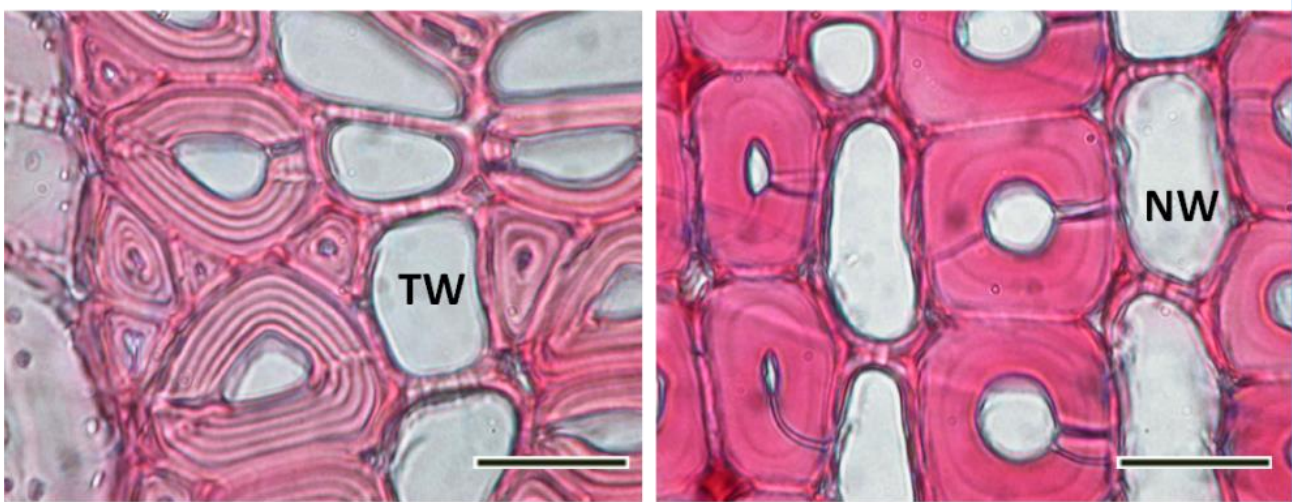

Laetia procera; Scale bar: $25 \mu \mathrm{m}$
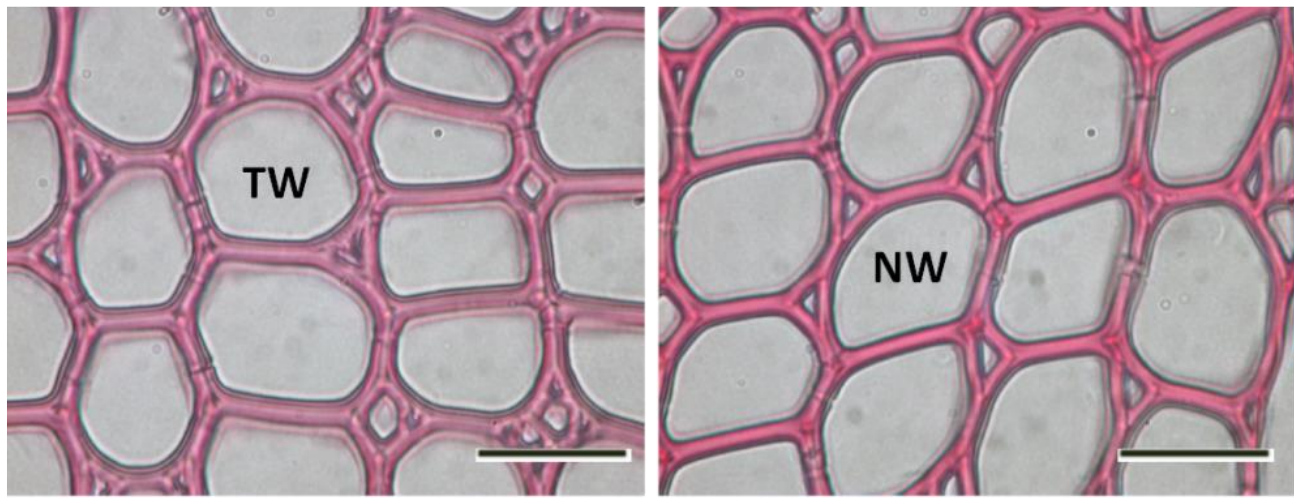

Simarouba amara; Scale bar: $25 \mu \mathrm{m}$

Figure 13. Comparative anatomy of tension wood and normal wood for 3 tropical species TW: tension wood; NW: normal wood

Table 6 - Differences between normal and reaction wood.

\begin{tabular}{|l|l|l|l|l|l|l|l|l|l|}
\hline Type & $\alpha_{m}$ NW & $\alpha_{m}$ RW & RW/NW & LS NW & LS RW & RW/NW & $S M_{b}$ NW & $S M_{b}$ RW & RW/NW \\
\hline SW & 410 & -2103 & -5.1 & 0.15 & 2.10 & 14.4 & 21.08 & 9.01 & 0.43 \\
\hline HW & 712 & 2334 & 3.3 & 0.15 & 0.75 & 5.0 & 25.20 & 28.85 & 1.15 \\
\hline HW GL & 796 & 2255 & 2.8 & 0.17 & 0.89 & 5.3 & 25.48 & 28.42 & 1.12 \\
\hline HW GLC & 522 & 3579 & 6.9 & 0.15 & 1.22 & 7.9 & 19.16 & 24.58 & 1.28 \\
\hline HW LGL & 668 & 2174 & 3.3 & 0.17 & 0.53 & 3.0 & 22.95 & 29.21 & 1.27 \\
\hline HW NGL & 637 & 1995 & 3.1 & 0.11 & 0.31 & 2.9 & 27.89 & 32.18 & 1.15 \\
\hline
\end{tabular}

SW: Softwood; HW: hardwood; NW: normal wood; RW: reaction wood;

GL: gelatinous layer; GLc: multi-layered GL; LGL: lignified GL; NGL: no GL; $\alpha_{m}$ : maturation strain; $L S$ : longitudinal shrinkage;

$S M_{b}$ : basic specific modulus; RW/NW: ratio between RW and NW values 
There is a clear distinction between wood types for the parameters describing force generation (Fig. 14) which confirms RW as force generator: compression (negative strain/stress) for CW, slight tension for NW, high tension for TW. Median $\alpha_{m}$ is very high, around $2200 \mu$ strain $(0.22 \%)$ in absolute value for both RWs, much lower ( $620 \mu$ strain) for NW. Median $\sigma_{m}$ is not so different, in absolute value, between CW (-9.5 $\mathrm{MPa}$, compression) and NW (+6.6 MPa, tension), due to the low MOE value (median $5.5 \mathrm{GPa})$ for CW (10.2 GPa for NW). The difference increases for TW (+31 MPa, tension) due to the higher median value of MOE (14.5 G pa), so tensile stress is nearly 5 times higher in TW as compared to NW. For a small new ring portion of $100 \mathrm{~mm}^{2}$ ( $50 \mathrm{~mm}$ wide, $2 \mathrm{~mm}$ thick) the force created in the CW (around $1 \mathrm{KN}$ ) or TW (around $3 \mathrm{KN}$ ) sectors is very high.

\begin{tabular}{|c|c|c|c|c|c|c|c|c|c|c|c|}
\hline \multicolumn{2}{|c|}{$\begin{array}{c}\text { Strain } \\
(\mathrm{CW})\end{array}$} & \multicolumn{2}{|c|}{$\begin{array}{l}\text { Strain } \\
\text { (NW) }\end{array}$} & \multicolumn{2}{|c|}{$\begin{array}{c}\text { Strain } \\
\text { (TW) }\end{array}$} & \multicolumn{2}{|c|}{$\begin{array}{c}\text { Stress } \\
(\mathrm{CW})\end{array}$} & \multicolumn{2}{|c|}{$\begin{array}{c}\text { Stress } \\
(\mathrm{NW})\end{array}$} & \multicolumn{2}{|c|}{$\begin{array}{c}\text { Stress } \\
\text { (TW) }\end{array}$} \\
\hline 4500 & & 4500 & & 4500 & $-\bullet$ & 72 & $\bar{\sigma}$ & & 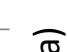 & 72 & t \\
\hline 3500 & & 3500 & 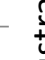 & 3500 & & 64 & $\Sigma$ & 64 & $\Sigma$ & 64 & \\
\hline 2500 & & 2500 & & 2500 & 舟 & 56 & $b^{2}$ & 56 & $b^{\varepsilon}$ & 56 & \\
\hline 1500 & & 1500 & 9 & 1500 & 1 & 48 & & 40 & & 10 & \\
\hline 500 & & 500 & $\$$ & 500 & . & 32 & & 32 & * & 32 & \\
\hline-500 & & -500 & & -500 & & 24 & & 24 & & 24 & \\
\hline-1500 & & -1500 & & -1500 &.$\frac{\Xi}{\pi}$ & 16 & & 16 & & 16 & \\
\hline-2500 & & -2500 & & -2500 & $\stackrel{\underline{n}}{\underline{z}}$ & 0 & & $\begin{array}{l}8 \\
0\end{array}$ & 自 & $\begin{array}{l}8 \\
0\end{array}$ & $\begin{array}{l}\bar{\pi} \\
\stackrel{\bar{N}}{\Sigma}\end{array}$ \\
\hline-3500 & & -3500 & & -3500 & & -8 & 里 & -8 & & -8 & $b^{\varepsilon}$ \\
\hline-4500 & & -4500 & & -4500 & & -16 & - & -16 & & -16 & \\
\hline
\end{tabular}

Figure 14. Distribution of maturation strain and initial maturation stress for different wood types $\alpha_{m}$ : maturation strain ( $\mu$ strain) $\sigma_{m}$, initial maturation stress (MPa);

CW: compression wood; NW: normal wood; TW: tension wood

The parallel regular progression of values for $S M_{b}$ in Fig. 15 reflects the fact that the MFA decreases from CW (up to $50^{\circ}$ ) to TW (near to $0^{\circ}$ ), with, however, a large overlap between NW and TW and a smaller one between NW and CW. This is not true for $L S$ (Fig. 15 and Fig. 16): both RWs have a high $L S$ while NW keeps a very low $L S$ level (less than $0.4 \%$ ).

The relationship between $L S$ and $\alpha_{m}$ (Fig. 16), $\alpha_{m}$ and $S M_{b}$ (Fig. 17) or $L S$ and $S M_{b}$ (Fig. 18) shows different patterns for NW, CW and TW. It should be noted that $\alpha_{m}$ and green wood properties ( $L S$ and $S M_{b}$ ) are not strictly measured on the same material and this contributes to lower correlations between them.

Absolute value of $\alpha_{m}$ grows with $L S$ (Fig. 16) for both RW types but there is no significant relationship for NW. Moreover, there are no significant difference for NW between softwoods and hardwoods. The high experimental measurement uncertainties for NW may be the reason for this lack of significant difference.

$\alpha_{m}$ decreases in absolute value for both TW and CW but there is no significant relationship for NW nor difference between softwoods and hardwoods for the same reason as above. 


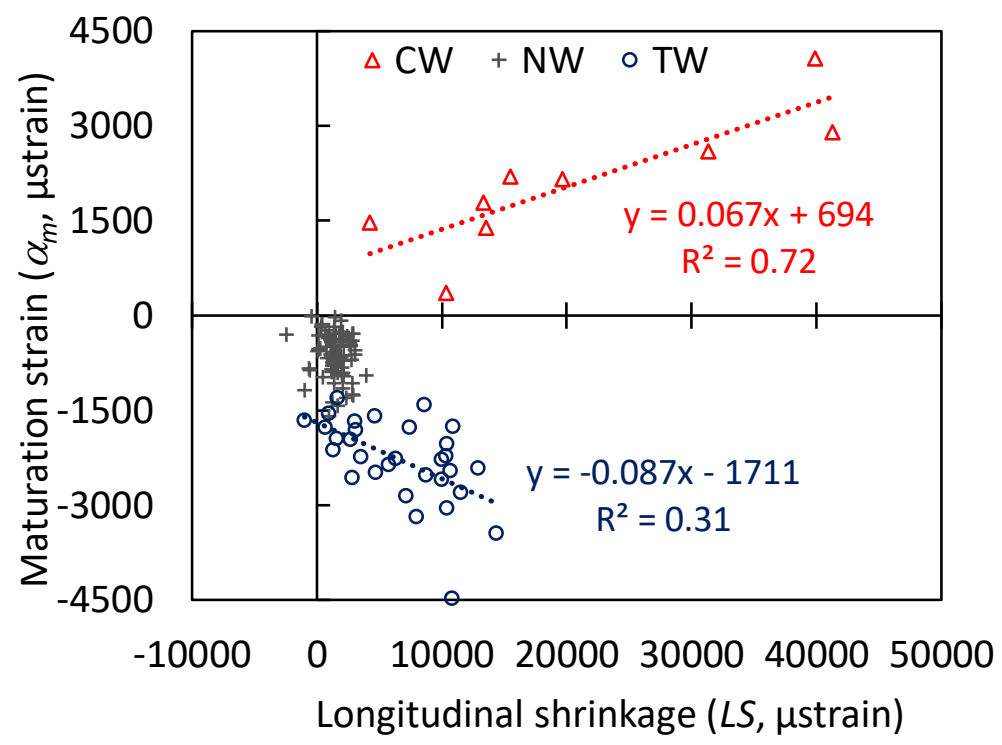

Figure 16. Evolution of maturation strain with longitudinal shrinkage. CW: compression wood; TW: tension wood; NW: normal wood for both softwoods and hardwoods (no significant difference); $\mu$ strain: micro deformation $\left(10^{-6}\right)$

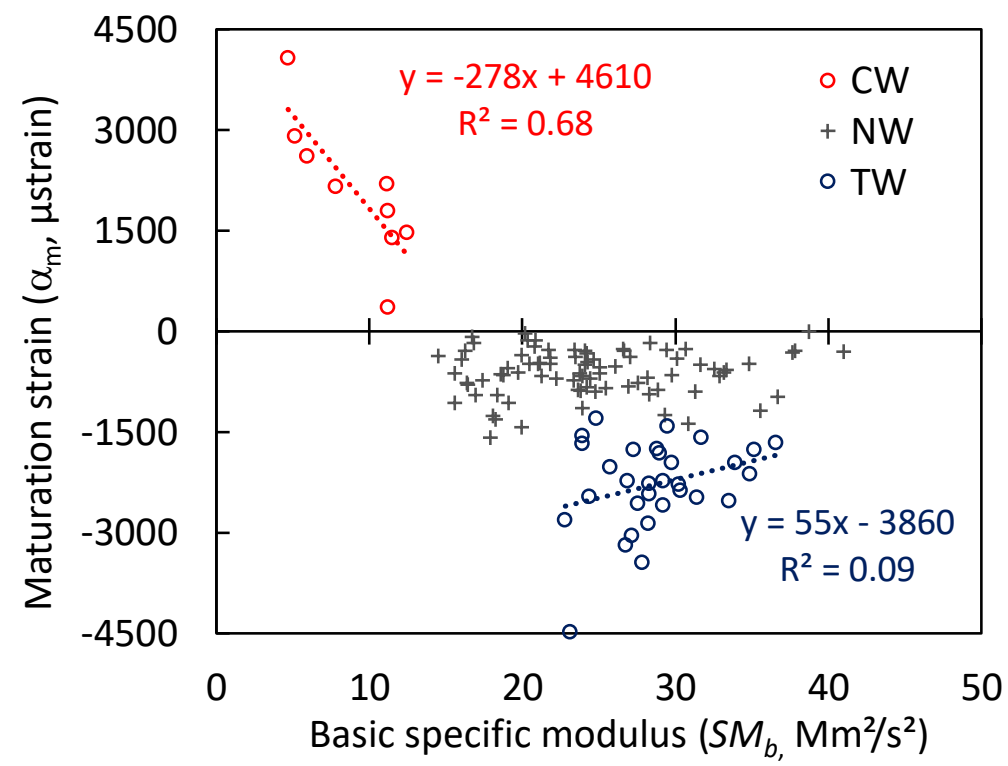

Figure 17. Evolution of longitudinal maturation strain with basic specific modulus Same legend as Fig. 16. 


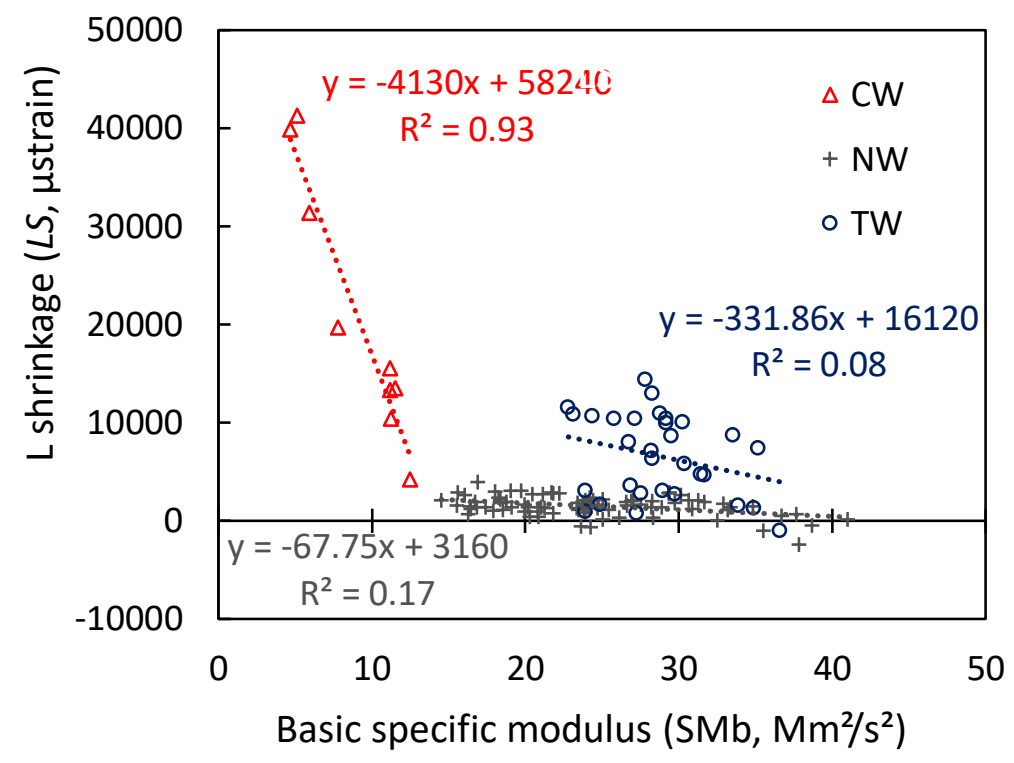

Figure 18. Evolution of longitudinal shrinkage with basic specific modulus. Same legend as Fig. 16

$L S$ and $S M_{b}$ are measured on the same rod so the experimental uncertainties are lower. For all wood types $L S$ decreases significantly when $S M_{b}$ increases (Fig. 18). But the evolution is very steep for $C W$ while it is smooth for NW with no significant difference between softwoods and hardwoods. In the case of TW there seems to exist two different behaviours. A group of species known to possess G-layer fibres have higher $L S$, while the other behaves more like NW. It is interesting to note that the range of specific modulus is rather large for tension wood and is overlapped by the NW range. The higher values for $\alpha_{m}$ in TW (for Glayer fibre group) are associated with the lower specific modulus.

Based on these observations CW and TW cannot be considered as an extension of NW in a single model.

\section{Conclusion and discussion}

Improvements in the use of the single hole method.

A simple conversion coefficient $(\phi)$ was obtained between growth stress indicator (GSI) given by the single hole method and $\alpha_{m}$ using $S M_{b}$. The proportionality is true within a tree in all cases, hence GSI can be directly used for biomechanical studies at tree level.

\section{Estimation of growth forces}

The growth force at a given angular position depends on 4 parameters

$$
F=A \cdot S M_{b} \cdot B D . \alpha_{m}
$$

$A$ (section area) is directly proportional to ring width (be it annual or not, as in tropical species). $S M_{b}$ and $B D$ needs the measurement of green wood volume $\left(V_{g}\right)$, green wood mass $\left(M_{g}\right)$, specific modulus in the green state $\left(S M_{g}\right)$, green rod dimensions $\left(L_{g}, T_{g}, R_{g}\right.$, for rods cut in the $L, R, T$ directions), and anhydrous mass $M_{0}$. Measurement at the same time of anhydrous wood rod volume $\left(V_{0}\right)$ and rod $L$ dimensions $\left(L_{0}, T_{0}\right.$, $R_{0}$ ) add useful information like total volumetric shrinkage (VS), L shrinkage (LS), R shrinkage (RS), or crosssectional shrinkage (VS-LS). Using the definition of the parameters, they can be calculated from these measurements in the green and anhydrous state:

$$
\begin{aligned}
& B D=M_{0} / V_{g} \\
& S M_{b}=S M_{g} \cdot D_{g} / B D \\
& V S=\left(V_{g}-V_{o}\right) / V_{g}
\end{aligned}
$$




$$
\begin{aligned}
& L S=\left(L_{g}-L_{0}\right) / L_{g} \\
& R S=\left(R_{g}-R_{0}\right) / R_{g} \\
& \alpha_{m}=\phi . G S I
\end{aligned}
$$

This calibration factor depends on elastic green wood properties and was found to be very well predicted by $S M_{b}$, over a very wide range of $S M_{b}\left(5\right.$ to $\left.40 \mathrm{Mm}^{2} / \mathrm{s}^{2}\right)$ using the linear equation:

$$
\phi=-0.475 . S M_{b}+25.24
$$

If $\alpha_{m}$ measurement (on standing tree) is not possible (or was not done) a small portion of trunk can be used in order to measure all parameters except for $\alpha_{m}$. It appears that measurements of $L S$ allow a rough estimate of $\alpha_{m}$ but only for CW and TW (Fig. 16).

For $\mathrm{CW}$, a linear equation can be used to transform $L S$ (in $\mu$ strain) into $\alpha_{m}$ (in $\mu$ strain):

$$
\alpha_{m}=0.067 . L S+694
$$

For TW it can be:

$$
\alpha_{m}=-0.087 . L S-1711
$$

For NW, the only possibility is to use a constant mean value (Table 6):

$$
\begin{aligned}
& \alpha_{m}=410 \mu \text { strain for softwoods } \\
& \alpha_{m}=712 \mu \text { strain for hardwoods }
\end{aligned}
$$

Very good proportional relationships were established for the relationship between green and air-dry state for density, specific modulus, MOE and shear modulus $\left(G_{T L}\right.$ and $\left.G_{R L}\right)$. Hence air-dry wood properties can be used whenever no data is available for green wood. If there are only data on air-dry wood, including total shrinkage values $(V S, R S, L S)$ the estimation of growth forces can still be done with reasonable validity. Very good proportional relationships were established between $B D$ and $D D, S M_{b}$ and $S M_{d}$ :

$$
B D=0.826 . D D ; S M_{b}=1.11 . S M_{d}
$$

The conversion coefficient $B D / D D$ can be corrected by the volumetric shrinkage, if necessary, using the equation:

$$
B D / D D=-0.49 . V S+0.88
$$

Green ring width $\left(R W_{g}\right)$, needed for the calculation of the surface area $A$, can be related to dry ring width $\left(R W_{d}\right)$ using radial shrinkage between green and air-dry state that can be roughly calculated as $4 / 10$ of the total radial shrinkage $(R S)$ assuming that standard air-dry moisture content is $12 \%$ and fibre saturation point (FSP) is $30 \%$. If the studied wood portion does not include a whole ring, it is likely to have shrunk tangentially as well, so that the correction factor for $A$, to account the T shrinkage, should involve the cross-sectional shrinkage, given by $4 / 10$ of VS-LS.

Further experiments should be done on species with different types of RW in order to assess the discrepancies between such simple rules and experimental measurements of $F$. In the discussion that follows, some suggestions for improvement will be made.

\section{Maturation strain and hygroscopic shrinkage in the longitudinal direction}

In a fibre composite, a physical action such as heating induces strains very different in a direction nearly parallel or perpendicular to fibre direction (Korb et al 1998, Sridhatra \& Vilaseca 2020) and micromechanical models based on properties of matrix and fibre are effective in predicting this expansion or shrinkage (Cave 1972, Bowles \& Tompkins 1988). 
In the cell wall, we can imagine that during lignin deposition within existing porosity in the cellulose - hemicellulose network, strains should appear both in the matrix and in the cellulose network, generating maturation strains (Sugiyama et al 1993, Okuyama et al. 1994). In the same way, during drying, water molecules extraction from the nano-porosities within matrix, and the cellulose network causes hygrometric shrinkage (Harris \& Meylan 1965, Watanabe \& Norimoto 1996). The models used for the prediction of such strains are exactly the same (Yamamoto et al 1998, Yamamoto et al 2001, Alméras et al 2005a) and are applied to the same matrix - cellulose network. As for specific modulus, due to the honeycomb structure of wood, the longitudinal strains should be the same at the cell wall and at the honeycomb level. This gives very good reasons for finding strong relationships between maturation and hygroscopic strains at the cell wall level, in the L direction.

Besides the complexity of the models, three main parameters are needed: micro-fibril angle, lignification or hygroscopic strains of the matrix, organization of the cellulosic nano-fibres within the microfibrils, with or without internal matrix occurrence (Chang et al 2015, Alméras \& Clair 2016, Gorshkowa et al 2018) and associated lignification or hygroscopic strains. The most basic model assumes that lignification and hygroscopic strains are constant while MFA changes. The predicted tendency for NW seems to be rather good in the very large range of MFA values, but the uncertainty of experimental values is high for maturation strains.

\section{Reaction wood versus normal wood}

There is a debate about whether RW is a mere continuity of NW or a shift from one strategy to another. Most of the time RW alone is considered as "muscle" able to produce a motor action through force dissymmetry between the upper and lower faces of the inclined woody axis. But if we admit that a muscle action is basically generating forces, NW has also a muscle function, thanks to the behaviour of tracheids and fibres during their biological life (before cell death). Oblique growth of woody axes at low inclination angles (below $10^{\circ}$ ) is regulated by a motor action involving only NW. Triggering of RW formation is clearly triggered by genetic expression (Gardiner et al 2014) and seems to be used for severe posture reaction (high motor action) in case of oblique growth at steep angles (branches) or vertical restoration after accidental inclination. These are the situations mostly investigated for RW studies or posture control.

Maturation strain $\alpha_{m}$ provides a continuum of wood types from CW to TW through NW, but it is difficult to define a definitive range of values for each wood type within a species and to decide whether there is an overlap of $\alpha_{m}$ ranges at the frontier between NW and CW or TW. In the anatomical field, the frontier is clearer for softwoods. Despite differences between mild and severe CW, both exhibit all the attributes of $\mathrm{CW}$, with gradations of parameters (lignin content, MFA and $L S$ ). The possibility to extend the models to CW seems possible using refinements in the model (Alméras et al 2005a) or a different swelling behaviour of the matrix for the compression wood (Yamamoto et al 1998).

For hardwoods, besides the regulation in pure NW there is a transition with wood containing a growing proportion of TW fibres (Trénard \& Guéneau 1975, Fang et al 2008, Gardiner et al 2014). This is why, in this study, TW specimens were all $100 \%$ tension wood fibres (at least it was verified for G-layer TW). For TW the only consistent way to analyse experimental results is to imagine a complex cellulose network within the gelatinous layer (Alméras \& Clair 2016, Gorshkova et al 2018) which could explain high $\alpha_{m}$, high $L S$ and rather low $S M$ for steep MFA, as found in this experiment.

Moreover, rather large variations of $\alpha_{m}$ for NW are poorly related to large variation in SM (and to MFA). This can be an artefact of the use of trees with large sectors of RW. The same kind of experiment ought to be made on trees of the same species with low-angle oblique growth (such as coppice shoots) yielding large $\alpha_{m}$ variations with no RW occurrence. $L S$ should be measured with a higher precision than in this study (using strain transducers for example).

The similarity between variation of $\alpha_{m}$ and $L S$ was less obvious for NW in our experiment, but two explanations can be given for this poor correlation: i) the two properties were not measured at the exact same place in the tree and the angular variations of properties can be very sharp, ii) the relative accuracy of $L S$ measurement was much lower than for $\alpha_{m}$ in NW. Lower angular gradients (oblique growth with no $R W$ ), better $L$ shrinkage measurement accuracy together with better pairing of specimens (measuring maturation strains by glued strain gages before cutting the $L$ shrinkage specimen at the same location) would be important improvements in the material and methods approach. 
Although no single model seems to explain NW and RW, general trends of predictions by physical models yield an influence of $S M$ on $\alpha_{m}$ and $L S$ variations within a species that applies both to NW and RW. The models need also information about strains associated with lignification or water departure within each cell-wall component (cellulose micro-fibril, hemicelluloses and lignin).

For RW, large variations of $\alpha_{m}$ (and $L S$ ) are linked to great changes in chemical composition, e.g., the proportion of the main polymer such as lignin, but also changes in the distribution of:

- lignin monomers: ratio syringyl/guaiacyl for hardwood without G-layer (Baillères et al 1995), ratio hydroxphenyl/guaiacyl for severe compared to mild CW (Nanayakkara et al 2009)

- hemicelluloses sugar origin: ratio galactose/arabinose (Brennan et al 2012)

Although the chemical variations are lower in NW, they may complement the influence of MFA on both $\alpha_{m}$ and $L S$. A single model for NW and RW will probably be rather simple using a few chemical indicators.

For TW there is a need for further investigation on different types of solution (microstructure and chemical composition) allowing very high $\alpha_{m}$ on one side of a tree. Using trees with clear TW sector (100\% of TW fibres) for some species with the different types of TW, a study of the variations between severe and mild TW based on variations of high $\alpha_{m}$ and high $L S$ should be done in conjunction with investigations into chemistry of the matrix and ultra-structure of cellulose.

\section{Data accessibility}

Data are available online: $\underline{\text { https://doi.org/10.5281/zenodo.4695043 }}$

\section{Acknowledgements}

A previous version of this article has been peer-reviewed and recommended by Peer Community In Forest and Wood Sciences (https://doi.org/10.24072/pci.forestwoodsci.100006).

\section{Conflict of interest disclosure}

The authors declare that they have no financial conflict of interest with the content of this article.

\section{Abbreviations and notations}

$\begin{array}{ll}A, A_{d} & \text { surface area of a ring sector, value in dry state } \\ C W & \text { compression wood } \\ D_{g}, B D, D D & \text { green density, basic density, air-dry density (cf. } \rho \text { ) } \\ D P_{x} & \text { distance to pith at angular position x } \\ E, E_{L} & \text { modulus of elasticity in L direction (cf. MOE) } \\ E_{g}, E_{d} & \text { green, air-dry MOE } \\ E_{L} / G_{T L}, E_{L} / G_{R L} & \text { anisotropy factors } \\ E_{L} / \rho & \text { Specific modulus }(S M) \text { in } L \text { direction } \\ F & \text { growth force } \\ F S P & \text { fibre saturation point } \\ G, G_{T L}, G_{R L} & \text { shear modulus, } G \text { in TL plane, } G \text { in RL plane } \\ G_{T L g}, G_{R L g} & G_{T L}, G_{R L} \text { in the green state } \\ G S I & \text { growth stress indicator } \\ H W & \text { hardwood } \\ k & \text { factor for shear contribution (5/6 for rectangular cross section) } \\ L, L & \text { longitudinal direction, } L \text { dimension for condition } \mathrm{k} \\ L S & \text { total longitudinal shrinkage } \\ M, M_{0} & \text { mass, oven-dry mass } \\ M C, M C_{g}, M C_{d} & \text { wood moisture content, MC in green condition, MC in air-dry condition } \\ M F A & \text { mean microfibril angle relative to } L \text { direction }\end{array}$




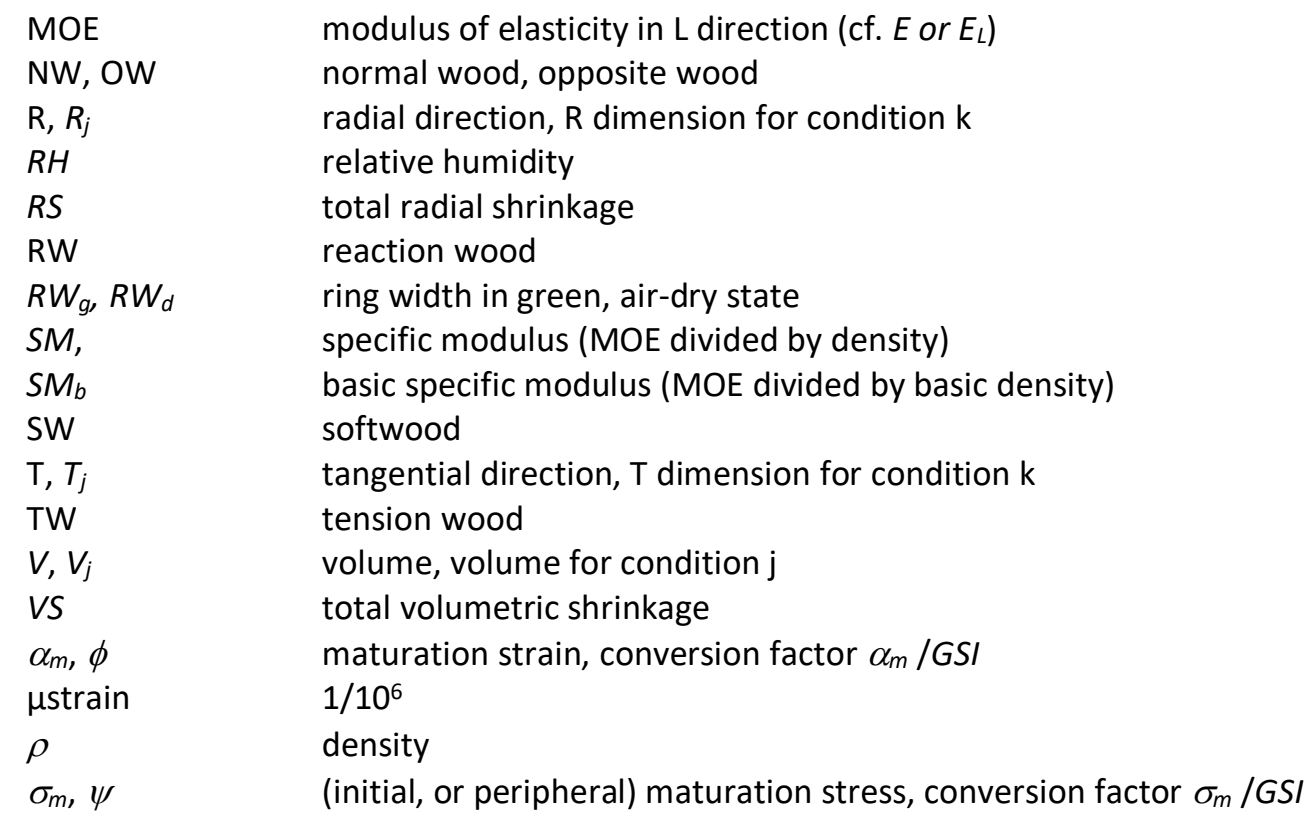

\section{References}

Alméras T, Gril J, Yamamoto H. 2005a. Modelling anisotropic maturation strains in wood in relation with fibre boundary conditions, microstructure and maturation kinetics. Holzforschung 59 (3), 347-353. https://doi.org/10.1515/hf.2005.057

Alméras T, Thibaut A, Gril J. 2005b. Effect of circumferential heterogeneity of wood maturation strain, modulus of elasticity and radial growth on the regulation of stem orientation in trees. Trees Structure and function 19 (4), 457-467. https://doi.org/10.1007/s00468-005-0407-6

Alméras T, Derycke M, Jaouen G, Beauchêne J, Fournier M. 2009. Functional diversity in gravitropic reaction among tropical seedlings in relation to ecological and developmental traits. Journal of Experimental Botany 60, 4397-4410. https://doi.org/10.1093/jxb/erp276

Alméras T, Clair B. 2016. Critical review on the mechanisms of maturation stress generation in trees. Journal of The Royal Society Interface 13 (122), 20160550. https://doi.org/10.1098/rsif.2016.0550

Alméras T, Jullien D, Gril J. 2018a. Modelling, Evaluation and Biomechanical Consequences of growth stress profiles inside tree stems. in: Plant Biomechanics, from Structure to Function at Multiple Scales, Anja Geitmann, Joseph Gril (eds), Springer International Publishing, pp.21-48. https://doi.org/10.1007/9783-319-79099-2 2

Alméras T, Ghislain B, Clair B, Secerovic A, Pilate G, Fournier M. 2018b. Quantifying the motor power of trees. Trees 32 (3), 689-702. https://doi.org/10.1007/s00468-018-1662-7

Archer RR. 1984. Application of a new method for the growth stress measurement for Pinus Caribea. IUFRO P5-01, Properties and utilisation of tropical woods, Manaus, Brasil, 19-23/11/1984.

Archer RR. 1986. Growth stresses and strains in trees. Springer, New York. https://doi.org/10.1007/978-3662-02511-6

Baillères H. 1994. Précontraintes de croissance et propriétés mécano-physiques de clones d'Eucalyptus (Pointe Noire, Congo) : hétérogénéités, corrélations et interprétations histologiques. Thèse en sciences du bois, Université Bordeaux 1 (In French). https://www.theses.fr/1994BOR10521

Baillères H., Chanson B., Fournier M., Tollier MT., Monties B. 1995. Structure, composition chimique et retraits de maturation du bois chez les clones d'Eucalyptus. Annales des sciences forestières 52 (2), 157172. https://doi.org/10.1051/forest:19950206

Bamber RK. 2001. A general theory for the origin of growth stresses in reaction wood: how trees stay upright. IAWA Journal, Vol. 22, 205-212. https://doi.org/10.1163/22941932-90000279

Barthélémy D, Caraglio Y. 2007. Plant architecture: a dynamic, multilevel and comprehensive approach to plant form, structure and ontogeny. Annals of Botany 99, 375-407. https://doi.org/10.1093/aob/mcl260 
Becker G, Beimgraben T. 2001. Occurrence and relevance of growth stresses in Beech (Fagus sylvatica L.) in Central Europe, Final Report of FAIR-project CT 98-3606, Coordinator G. Becker, Institut für Forstbenutzung und forstliche Arbeitwissenschaft, Albert-Ludwigs Universität, Freiburg, Germany, 323 p.

Bordonné P.A. 1989. Module dynamique et frottement intérieur dans le bois : mesures sur poutres flottantes en vibrations naturelles. Thèse de Doctorat en Sciences du Bois, Institut National Polytechnique de Lorraine, Nancy. https://www.theses.fr/1989NAN10387

Bowles DE, Tompkins SS. 1988. Prediction of coefficients of thermal expansion for unidirectional composites. Journal of Composite Materials 23, 370-388. https://doi.org/10.1177/002199838902300405

Boyd JD. 1972. Tree growth stresses -- Part V: Evidence of an origin in differentiation and lignification. Wood Science and Technology 6, 251-262. https://doi.org/10.1007/bf00357047

Brancheriau L., Baillères H. 2002. Natural vibration analysis of clear wooden beams: a theoretical review. Wood Science and Technology 36, 347-365. https://doi.org/10.1007/s00226-002-0143-7

Brémaud I, Ruelle J, Thibaut A, Thibaut B. 2013. Changes in viscoelastic vibrational properties between compression and normal wood, roles of microfibril angle and of lignin. Holzforschung 67, 75-85. https://doi.org/10.1515/hf-2011-0186

Brennan M, McLean JP, Altaner CM, Ralph J, Harris PJ. 2012. Cellulose microfibril angles and cell-wall polymers in different wood types of Pinus radiata. Cellulose 19, 1385-1404. https://doi.org/10.1007/s10570-012-9697-1

Cave ID. 1972. A theory of the shrinkage of wood. Wood Science and Technology 6, 284-292. ttps://doi.org/10.1007/bf00357050

Cave ID., Hutt L. 1968. The anisotropic elasticity of plant cell wall. Wood Science \& Technology 2, 268-278. https://doi.org/10.1007/bf00350273

Chang SS, Clair B, Ruelle J, Beauchêne J, Di Renzo F, Quignard F, Zhao GJ, Yamamoto H, Gril J. 2009. Mesoporosity as a new parameter in understanding of tension stress generation in trees. Journal of Experimental Botany 60, 3023-3030. https://doi.org/10.1093/ixb/erp133

Chang S S, Quignard F, Alméras T, Clair B. 2015. Mesoporosity changes from cambium to mature tension wood: a new step toward the understanding of maturation stress generation in trees. New Phytologist 205, 1277-1287. https://doi.org/10.1111/nph.13126

Clair B, Ruelle J, Beauchêne J, Prévost MF, Fournier M. 2006. Tension wood and opposite wood in 21 tropical rain forest species. 1. Occurrence and efficiency of the G-layer. IAWA Journal 27 (3), 329-338. https://doi.org/10.1163/22941932-90000158

Clair B, Alteyrac J, Gronvold A Espejo J, Chanson B, Alméras T. 2013. Patterns of longitudinal and tangential maturation stresses in Eucalyptus nitens plantation trees. Annals of Forest Science 70, 801-811. https://doi.org/10.1007/s13595-013-0318-4

Clair B., Thibaut B. 2014. Physical and mechanical properties of reaction wood, Chapter 6, in: The Biology of Reaction Wood, Springer Series in Wood Science, B. Gardiner et al. (eds). https://doi.org/10.1007/978-3-642-10814-3 6

Coutand C, Fournier M, Moulia B. 2007. The gravitropic response of polar trunk: key roles of prestressed wood regulation and the relative kinetics of cambial growth versus wood maturation. Plant Physiology 144 (2), 1166-1180. https://doi.org/10.1104/pp.106.088153

Cowdrey DR, Preston RD. 1966 Elasticity and microfibrillar angle in wood of Sitka spruce. Proceedings of the Royal Society of London B 166, 245-272. https://doi.org/10.1098/rspb.1966.0097

Fagerstedt KV, Mellerowicz E, Gorshkova T, Ruel K, Joseleau JP. 2014. Cell Wall Polymers in Reaction Wood. Chapter 3, in: The Biology of Reaction Wood, B. Gardiner et al. (eds). https://doi.org/10.1007/978-3$\underline{642-10814-3 \quad 3}$

Fahn A. 1990. Plant anatomy. Fourth edition. Pergamon press.

Fang CH, Clair B, Gril J, Liu SQ. 2008. Growth stresses are highly controlled by the amount of G-layer in poplar tension wood. IAWA Journal 29 (3), 237-246. https://doi.org/10.1163/22941932-90000183

Fournier M, Chanson B, Guitard D, Thibaut B. 1991a. Mechanics of standing trees: modeling a growing structure subjected to continuous and fluctuating loads. 1. Analysis of support stresses (in French). Annales des Sciences Forestières 48 (5), 513-525. https://doi.org/10.1051/forest:19910503 
Fournier M, Chanson B, Thibaut B, Guitard D. 1991b. Mechanics of standing trees: modelling a growing structure subjected to continuous and fluctuating loads. 2. Three-dimensional analysis of maturation stresses in a standard broadleaved tree. Annales des Sciences Forestières 48, 527-546 (in French). https://doi.org/10.1051/forest:19910504

Fournier M, Chanson B, Thibaut B, Guitard D. 1994. Measurements of residual growth strains at the stem surface, in relation to its morpholgy. Observations on different species. Annales des Sciences Forestières 51, 249-266. ttps://doi.org/10.1051/forest:19940305

Fournier M, Dlouha J, Jaouen G, Alméras T. 2013. Integrative biomechanics for tree ecology: beyond wood density and strength. Journal of Experimental Botany 64 (15), 4793-4815. https://doi.org/10.1093/jxb/ert279

Fournier M, Alméras T, Clair B, Gril J. 2014. Biomechanical action and biological functions. Chapter 5, in: The biology of reaction wood. B Gardiner et al. (eds), pp. 139-169. https://doi.org/10.1007/978-3-64210814-3 5

Gardiner B, Barnett J, Saranpää P, Gril J. 2014. The biology of reaction wood. Springer, Berlin, Heidelberg. DOI 10.1007/978-3-642-10814-3. https://doi.org/10.1007/978-3-642-10814-3

Ghislain B, Clair B. 2017. Diversity in the organisation and lignification of tension wood fibre walls-a review. IAWA Journal 38, 245-265. https://doi.org/10.1163/22941932-20170170

Ghislain B., Engel J., Clair B. 2019. Diversity of anatomical structure of tension wood among 242 tropical tree species. IAWA journal 40 (4), 765-784. https://doi.org/10.1163/22941932-40190257

Gordon JE. 1978. Structures or why things don't fall down, Penguin books. https://doi.org/10.1007/978-14615-9074-3

Gorshkova T, Chernova T, Mokshina N, Ageeva M, Mikshina P. 2018. Plant "muscles", fibers with a tertiary cell wall. New Phytologist 218 (1), 66-72. https://doi.org/10.1111/nph.14997

Gril J., Jullien D., Bardet S., Yamamoto H. 2017. Tree growth stress and related problems. Journal of Wood Science, 63 (5), 411-432. https://doi.org/10.1007/s10086-017-1639-y

Huang YS., Chen SS., Lin TP., Chen YS. 2001. Growth stress distribution in leaning trunks of Cryptomeria japonica. Tree Physiology 21, 261-266. https://doi.org/10.1093/treephys/21.4.261

Jullien D, Widmann R, Loup C, Thibaut B. 2013. Relationship between tree morphology and growth stress in mature European beech stands. Annals of forest science 70 (2), 133-142. https://doi.org/10.1007/s13595-012-0247-7

Korb G, Korab J, Groboth G. 1998. Thermal expansion behaviour of unidirectional carbon-fibre-reinforced copper-matrix composites. Composites Part A, 29A, 1563-1567. https://doi.org/10.1016/s1359$\underline{835 \times(98) 00066-9}$

Markwardt LJ, Wilson TRC. 1935. Strength and related properties of woods grown in the United States. USDA technical bulletin $\mathrm{N}^{\circ} 479$, Washington D.C.

Moore JR, Cown DJ, McKinley RB, Sabatia CO. 2015. Effects of stand density and seedlot on three wood properties of young radiata pine grown at a dry-land site in New Zealand. New Zealand Journal of Forestry Science (2015) 45:4. https://doi.org/10.1186/s40490-015-0035-x

Moulia B, Fournier M. 2009. The power and control of gravitropic movements in plants: a biomechanical and system biology view. Journal of Experimental Botany 60, 461-486. https://doi.org/10.1093/jxb/ern341

Moulia B, Bastien R, Chauvet-Thiry H and Leblanc-Fournier N. 2019. Posture control in land plants: growth, position sensing, proprioception, balance, and elasticity. Journal of Experimental Botany, 70 (14), 34673494. https://doi.org/10.1093/jxb/erz278

Nanayakkara B., Manley-Harris M., Suckling I.D., Donaldson LA. 2009. Quantitative chemical indicators to assess the gradation of compression wood. Holzforschung 63, 431-439. https://doi.org/10.1515/hf.2009.062

Okuyama T., Yamamoto H., Yoshida M., Hattori Y., Archer RR. 1994. Growth stresses in tension wood, role of microfibrils and lignification. Annals of forest science 51, 291-300. https://doi.org/10.1051/forest:19940308

Ruelle J. 2003. Comparative anatomy normal wood / reaction wood and observation of structure / properties relationships (in French). MS Thesis, Université de Nancy. 
Ruelle J, Yamamoto H, Thibaut B. 2007. Growth stresses and cellulose structural parameters in tension and normal wood from three tropical rainforest angiosperm species. Bioresources 2 (2), 235-251. https://doi.org/10.15376/biores.2.2.235-251

Ruelle J, Beauchêne J, Yamamoto H, Thibaut B. 2011. Variations in physical and mechanical properties between tension and opposite wood from three tropical rainforest species. Wood Science and Technology 45, 339-357. https://doi.org/10.1007/s00226-010-0323-9

Ruelle J. 2014. Morphology, Anatomy and Ultrastructure of Reaction Wood. Chapter 2, in: B. The Biology of Reaction Wood, Springer Series in Wood Science, Gardiner et al. (eds). https://doi.org/10.1007/9783-642-10814-3 2

Sasaki Y, Okuyama T, Kikata Y. 1978. The evolution process of the growth stress in the tree. The surface stress on the tree. Mokuzai Gakkaishi (Journal of the Japanese Wood Research Association) 29, 149157.

Senft J F, Bendtsen BA. 1985. Measuring microfibrillar angles using light microscopy. Wood and fiber science 17, 564-567.

Sridhara PK, Vilaseca F. 2020. Assessment of Fiber Orientation on the Mechanical Properties of PA6/Cellulose Composite. Appl. Sci. 10, 5565. https://doi.org/10.3390/app10165565.

Sugiyama K, Okuyama T, Yamamoyo H, Yoshida M. 1993. Generation process of growth stresses in cell walls: Relation between longitudinal released strain and chemical composition. Wood Science \& Technology 27, 257-262. https://doi.org/10.1007/bf00195301

Thibaut B, Chanson B, Fournier M, Jullien D. 1995. Valorisation du bois de châtaignier : prévoir et réduire les risques de roulure à la production, Rapport final contrat "Agriculture demain" MRT 91.G.0491, 12.95. (In French)

Thibaut B. 2019. Three-dimensional printing, muscles and skeleton: mechanical functions of living wood, Journal of Experimental Botany 70 (14), 3453-3466. https://doi.org/10.1093/jxb/erz153

Timell TE. 1986. Compression wood in gymnosperms, 3 vol., Springer, Berlin, 2210 pp. https://doi.org/10.1007/978-3-642-61616-7

Tocquard K, Lopez D, Decourteix M, Thibaut B, Julien JL, Label P, Leblanc-Fournier N, Roeckel-Drevet P. 2014. The molecular mechanisms of reaction wood induction. Chapter 4, in: The biology of reaction wood. B Gardiner et al. (eds). https://doi.org/10.1007/978-3-642-10814-3 4

Trénard Y, Guéneau P. 1975. Relations entre Contraintes de Croissance Longitudinales et Bois de Tension, dans le Hêtre (Fagus sylvatica L.). Holzforshung 29, 217-223. https://doi.org/10.1515/hfsg.1975.29.6.217

Vieilledent G, Fischer FJ, Chave J, Guibal D, Langbour P, Gérard J. 2018. New formula and conversion factor to compute basic wood density of tree species using a global wood technology database. American Journal of Botany 105 (10), 1-9. https://doi.org/10.1101/274068

Waghorn MJ, Mason EG, Watt MS. (2007). Influence of tree morphology, genetics, and initial stand density on outerwood modulus of elasticity of 17-year-old Pinus radiata. Forest Ecology and Management, 244(1-3), 86-92. https://doi.org/10.1016/j.foreco.2007.03.057

Watanabe U., Norimoto M. 1996. Shrinkage and elasticity of normal and compression wood in conifers. Mokuzai Gakkaishi (Journal of the Japanese Wood Research Association) 42, 651-658.

Watt MS, Clinton PW, Coker G, Davis MR, Simcock R, Parfitt RL, Dando J. 2008. Modelling the influence of environment and stand characteristics on basic density and modulus of elasticity for young Pinus radiata and Cupressus lusitanica. Forest Ecology and Management 255 (2008) 1023-1033. https://doi.org/10.1016/j.foreco.2007.09.086

Yamamoto H., Okuyama T., Yoshida M. 1998. Growth stress generation and microfibril angle in reaction wood. In: Microfibril angle in wood. International Association of Wood Anatomist, Christchurch, Butterfield BG (ed), pp 225-239.

Yamamoto H., Sassus F., Ninomiya M, Gril J. 2001. A model of anisotropic swelling and shrinking process of wood. Part 2. A simulation of shrinking wood. Wood Science and Technology 35, 167-181. https://doi.org/10.1007/s002260000074, errata: https://doi.org/10.1007/s002260100111

Yang JL, Baillères H, Okuyama T, Muneri A, Downes G. 2005. Measurement methods for longitudinal surface strain in trees, a review. Australian Forestry 68, 34-43. https://doi.org/10.1080/00049158.2005.10676224 
Yoshida M, Okuda T, Okuyama T. 2000. Tension wood and growth stress induced by artificial inclination in Liriodendron tulipifera Linn. and Prunus spachiana Kitamura f. ascendens Kitamura. Annals of forest science 57 (8), 739-746. https://doi.org/10.1051/forest:2000156

Yoshida M, Okuyama T. 2002. Techniques for measuring growth stress on the xylem surface using strain and dial gauges. Holzforschung 56 (5), 461-467. https://doi.org/10.1515/hf.2002.071

\section{Appendix 1 Measurements on Beech and Chestnut}

Large campaigns of in-situ maturation strain measurements using the CIRAD single hole method were performed on mature forest stands of beech and chestnut trees, in Europe. All data are available in the accompanying data file (see $\S$ "Data accessibility").

For beech, ten different plots were selected in five European countries: Austria, Denmark, France, Germany and Switzerland (Becker \& Beimgraben 2001, Jullien et al 2013). Trees (50 per plot) were all largedimension mature trees ready for harvesting and processing in the sawing and veneer industry. Eight holes every $45^{\circ}$ around the periphery were drilled at breast height and GSI was measured. Total height $(H), D B H$ and slenderness $(H / D B H)$ are reported in the data file accompanying this article.

The first hole position was positioned on the north face of the trunk. In order to obtain mean circumferential variations from groups of trees, the value $180^{\circ}$ was ascribed to the hole were GSI was maximum for the tree (Max).

There is a very significant positive relationship (at the $p=0.001$ level) between tree slenderness and all $G S /$ values when they are arranged in the same manner. This is true also for minimum, difference between maximum and minimum (Max-Min) and mean per tree value. Slender trees have higher values of maturation strains.

For chestnut (Thibaut et al 1995), only mature coppice shoots were measured with the same protocol except that the first hole was on the upper part of the stem, where the maximum GSI value is expected. Most of the coppice shoots had an oblique grown, in order to develop a globally equilibrated crown for the whole stump. In order to keep this oblique posture at a rather small angle, a dissymmetry of $F$ between upper and lower face of the shoot is necessary. There was a very significant positive correlation between shoot inclination ( $T I$ in \%) and GSI dissymmetry whatever was used to measure this dissymmetry: maximum minus minimum (Max-Min), upper GSI minus lower GSI (Max-180), coefficient of variation (CV) of the 8 GSI measurements for a shoot (Fig. A1).

From literature and former measurements, GSI up to $110 \mu \mathrm{m}$ (1400 $\mu$ strain for a conversion factor of $12.8 \mu$ strain/ $\mu \mathrm{m}$ ) relates to normal wood (NW) while GSI over $140 \mu \mathrm{m}$ (1800 $\mu$ strain) should be attributed to tension wood (TW). By sorting the chestnut shoots by Max GSI, it is possible to find 68 trees lower than $111 \mu \mathrm{m}$ called "no TW" trees and 69 trees higher than $140 \mu \mathrm{m}$ called "with TW". A mean angular profile can be drawn for the two shoot types.

Shoots without TW have a smaller mean inclination (6.38\%) than shoots with TW (14.5\%) and consequently, the mean dissymmetry of $\alpha_{m}$ is smaller for no TW tress (596 $\mu$ strain) than for trees with TW (1842 $\mu$ strain). 


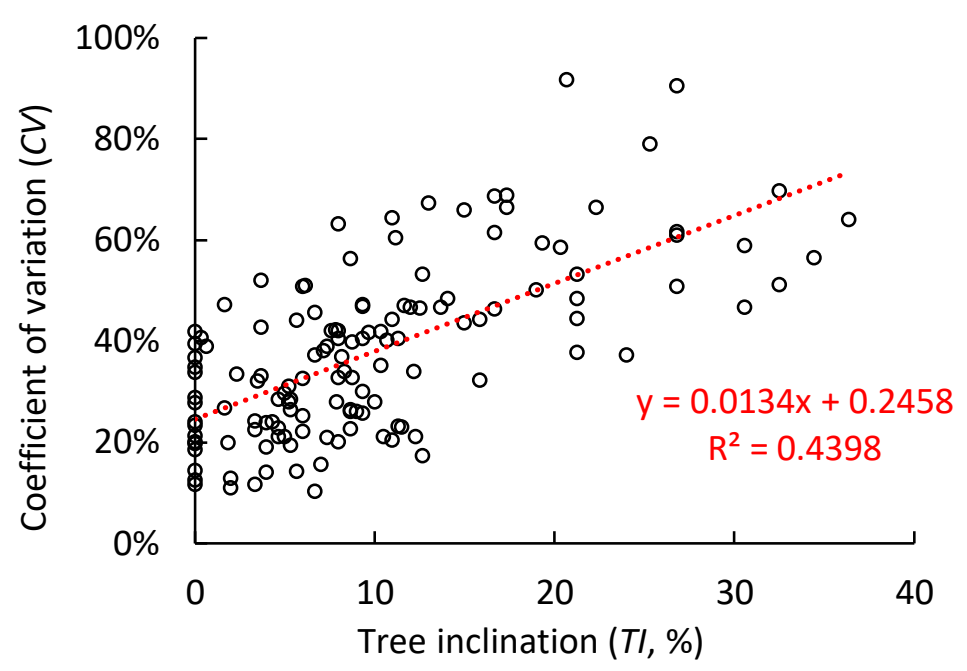

Figure A1. Relationship between trunk inclination (TI) and GSI dissymmetry for 161 chestnut shoots $C V$ : coefficient of variation of the 8 maturation strains for each shoot

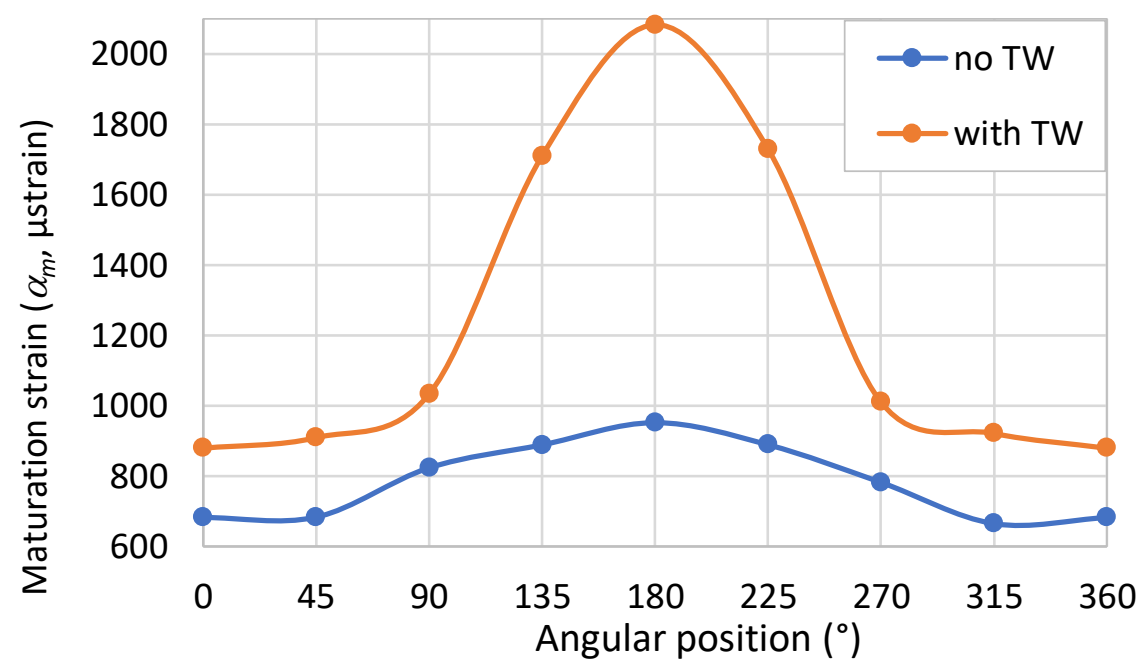

\begin{tabular}{|c|c|c|c|c|c|}
\hline Chestnut & Tree type & Max 国 & Nb trees & Max-Min & TI \\
\hline shoots & no TW & $<1400 \mu$ strain & 68 & 596 & $6.38 \%$ \\
\hline & TW & $>1800 \mu$ strain & 69 & 1842 & $14.5 \%$ \\
\hline
\end{tabular}

Figure A2. Mean peripheral variations of maturation strain for two types of trees

No TW: trees without tension wood; with TW: trees with tension wood

$180^{\circ}$ is always positioned on the upper face (hypothesised to be in the maximum tensile state)

Max ?m: mean value, for all the trees of the same type, at position $180^{\circ}$

Max: maximum value of the maturation strain within a tree

Min: minimum value of the maturation strain within a tree

Max-Min: mean value of the difference for all trees of the same type

TI: mean trunk inclination for all the trees of the same type 


\section{Appendix 2 Calculation of the conversion factor between GSI and $\alpha_{m}$}
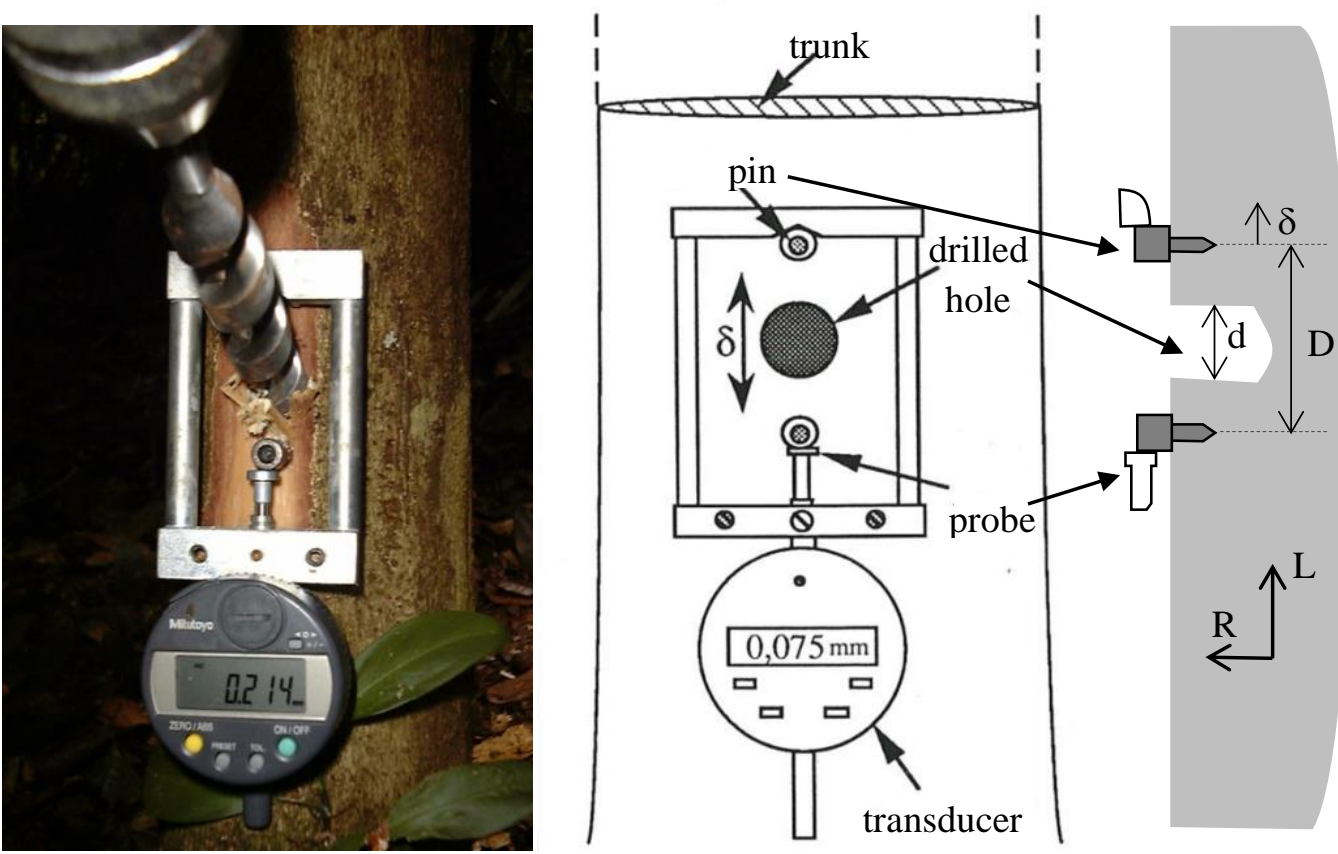

(a)

(b)

(c)

Figure A3. Measurement of maturation strain with the single-hole method. (a) Hole drilling operation (photo Bruno Clair); (b) schematic view in the LT plane (Baillères 1994); (c) radial section.

The growth stress indicator (GSI) given by the CIRAD single-hole method (Fig. A3) is the relative variation of distance $\delta$ between 2 points aligned in the direction $L$ and distant from $D$, following the drilling of a central hole of diameter d. Based on the solution of Archer (1984) for the drilling of an anisotropic material occupying a half plane, the expression of $\delta$ is as follows:

$$
\delta=\frac{D}{E_{L}}\left(\psi_{L} \sigma_{L}+\psi_{T} \sigma_{T}\right)
$$

Here $\sigma_{L}$ and $\sigma_{T}$ are the components of the stress in the half plane, in $L$ and $T$ directions, respectively, and $\psi_{L}, \psi$ are constants given by:

$$
\begin{gathered}
\psi_{L}=\left(v_{L T}+\alpha_{1}\right) \frac{\left(1-\gamma_{1}\right)^{2}\left(1-\gamma_{2}\right)}{4 \gamma_{1}\left(\gamma_{1}-\gamma_{2}\right)}\left(-1+\sqrt{1+\frac{4 \gamma_{1}}{\left(1-\gamma_{1}\right)^{2}} \frac{d^{2}}{D^{2}}}\right) \\
-\left(v_{L T}+\alpha_{2}\right) \frac{\left(1-\gamma_{1}\right)\left(1-\gamma_{2}\right)^{2}}{4 \gamma_{2}\left(\gamma_{1}-\gamma_{2}\right)}\left(-1+\sqrt{1+\frac{4 \gamma_{2}}{\left(1-\gamma_{2}\right)^{2}} \frac{d^{2}}{D^{2}}}\right) \\
\psi_{T}=-\left(v_{L T}+\alpha_{1}\right) \frac{\left(1-\gamma_{1}\right)^{2}\left(1+\gamma_{2}\right)}{4 \gamma_{1}\left(\gamma_{1}-\gamma_{2}\right)}\left(-1+\sqrt{1+\frac{4 \gamma_{1}}{\left(1-\gamma_{1}\right)^{2}} \frac{d^{2}}{D^{2}}}\right) \\
+\left(v_{L T}+\alpha_{2}\right) \frac{\left(1+\gamma_{1}\right)\left(1-\gamma_{2}\right)^{2}}{4 \gamma_{1}\left(\gamma_{1}-\gamma_{2}\right)}\left(-1+\sqrt{1+\frac{4 \gamma_{2}}{\left(1-\gamma_{2}\right)^{2}} \frac{d^{2}}{D^{2}}}\right)
\end{gathered}
$$

$\alpha_{1}, \alpha_{2}$ are the two solutions of the 2 nd degree equation $\alpha^{2}-s . \alpha+p=0$ where $s$ and $p$ depend on the Young's moduli $E_{L}, E_{T}$ in the $\mathrm{L}$ and T directions, respectively, the shear modulus $G_{L T}$ in $L T$ plane and the Poisson's ratio $v_{L T}$ : 


$$
s=\alpha_{1}+\alpha_{2}=E_{L} / E_{T} ; p=\alpha_{1} \cdot \alpha_{2}=E_{L} / G_{L T}-2 \cdot v_{L T}
$$

and:

$$
\gamma_{1}=\left(\sqrt{\alpha_{1}}-1\right) /\left(\sqrt{\alpha_{1}}+1\right) \quad ; \quad \gamma_{2}=\left(\sqrt{\alpha_{2}}-1\right) /\left(\sqrt{\alpha_{2}}+1\right)
$$

Here the contribution of the tangential component of the stress was neglected, so that:

$$
\delta \approx D \cdot \psi_{L} \cdot\left(\sigma_{L} / E_{L}\right)
$$

$\delta$ expressed in $\mu \mathrm{m}$ is the growth stress indicator $(G S I)$ and can be converted into maturation strain $\left(\alpha_{m} \approx\right.$ $\sigma_{L} / E_{L}$ ) using the conversion parameter $\phi$ :

$$
\alpha_{m}=\phi . \mathrm{GSI}, \alpha_{m} \text { in } \mu \text { strain }=10^{-6}, \mathrm{GSI} \text { in } \mu \mathrm{m}, \phi=1 /\left(\mathrm{D} \cdot \psi_{L}\right) \text { in } \mu \text { strain } / \mu \mathrm{m}
$$

Baillères in his PhD thesis (1994) used this calculation for 13 different species. Using elastic orthotropic constants coming from statistical models built by Guitard and El Amri (1987), he obtained $\phi$ values ranging from -9.1 to $-14.9 \mu \varepsilon / \mu \mathrm{m}$. However, special wood types such as RW were not considered. Besides, we do not have the 9 elastic constants for the different species and wood types (NW and RW) of this study. From Guitard \& El Amri and other literature we have built a data collection of the 6 diagonal moduli $\left(E_{L}, E_{T}, E_{R}\right.$, $G_{L T}, G_{L R}, G_{T R}$ ) for different species with known densities. We estimated the non-diagonal constants ( $v_{L T}, v_{T L}$ $\left.v_{\mathrm{LR}}, v_{\mathrm{RL}}, v_{\mathrm{RT}}, v_{\mathrm{TR}}\right)$ using Guitard \& El Amri's statistical models and then made the whole calculation of $\phi$ values for these 96 cases (Excel sheet "Conversion factor GSI" in the accompanying data file (see § "Data accessibility" below). In order to make that calculus, we have to find the 2 solutions of a second-degree equation, which is not possible if the determinant is negative. That happened for a few cases (8 with very low $E / G$ values). There was a very high correlation level between $\phi$ and the ratio $E L / G_{T L}$ and a logarithmic equation gives a very high $\mathrm{R}^{2}$ (Fig. A4):

$$
\phi=-7.57 . \operatorname{Ln}\left(E_{L} / G_{T L}\right)+34.665
$$

This equation can be used to calculate $\phi$ with only one anisotropic ratio.

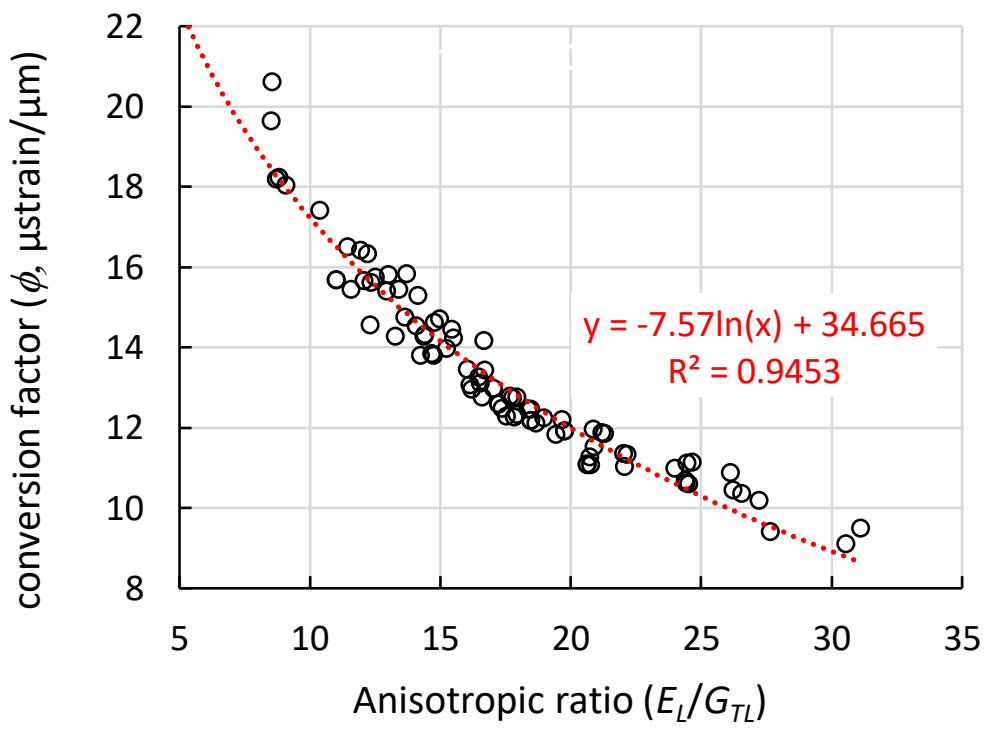

Fig. A4 - Link between conversion coefficient $\phi$ and anisotropy ratio 